\title{
The Legacy of Treasure: Manuscript
}

\author{
Dr. Shuchi Srivastava* \\ India \\ *Corresponding author: Dr. Shuchi Srivastava, Assistant Professor, Department of \\ Anthropology, National Post Graduate College, Lucknow, India.
}

Assistant professor, Department of Anthropology, National Post Graduate College, NAAC 'A' Grade, CPE, Affiliated College of University of Lucknow, Lucknow,

\author{
Received Date: April 01, 2020 \\ Published Date: April 15, 2020
}

\begin{abstract}
The transmission of cultural heritage from one generation to another could be possible through various mediums and manuscript is one of them. In the form of manuscript collection, all the ancient civilizations have preserved their precious cultural heritage. In fact, manuscripts are the legacy of treasure for them. The present paper deals with the origin, historical background and various other aspects of the precious heritage - 'Manuscript'. Therefore mainly, the secondary sources of data have been used for the study. Most of the facets are described with the help of illustrations, bring from various sources. It is found that the beginning of a writing tradition brought a major change to the human civilization. The manuscripts available in different forms reflect the background of the cultural heritage of the civilizations. These are preserved in different libraries, academic institutions, museums, religious institutions and likewise in private collections of different corner of the globe. Due to different factors, numerous manuscripts are now in a very vulnerable condition. The available manuscripts are tried to preserve and make them accessible as far as possible. It is suggested that every citizen of all the nations should feel his/her duty to preserve this precious heritage and it is only possible through making general awareness regarding significance of the explicit knowledge of our ancestors -'Manuscript'.
\end{abstract}

Keywords: Manuscript, Cultural heritage, Legacy of treasure, Manuscript preservation

\section{Introduction}

The transmission of cultural heritage from one generation to another could be possible through various mediums and manuscript is one of them. Manuscript of a country not only carries its cultural heritage to each and every corner of it but also carries that precious heritage to other parts of the world. In the form of manuscript collection, all the ancient civilizations have preserved their precious cultural heritage. In fact, manuscripts are the legacy of treasure for them. India is not exceptional in this regard. There is a treasure of valuable manuscripts in India showing the richness of its traditional culture.

\section{Etymology, Meaning and Definition}

Etymologically, the word 'Manuscript' has been originated from the Latin words - 'Manus' (by hand) and 'Scriptus' (written). Thus, it means 'a document written with a person's own hand'. Traditionally, a 'Manuscript' was any document written by hand. Once practical typewriters became available, typewritten documents were also being included in its category, which were not mechanically printed or replicated in some indirect or automatic way. Now, the term has included any written, typewritten, or word-processed copy of the work of authors. It must not be a printed version of the same. All those documents and books are included in the category of manuscripts which were written before the invention of printing. On the basis of contents, manuscripts cannot be determined. Mathematical calculations, maps, music notation, explanatory figures or illustrations may be combined with writing.

The National Mission for Manuscripts, India defines, 'A manuscript is a handwritten composition on paper, bark, cloth, metal, palm leaf or any other material dating back at least seventyfive years that has significant scientific, historical or aesthetic value' [1].

\section{Methodology}

The present paper deals with the origin, historical background and various other aspects of the precious heritage - 'Manuscript'. It is basically a descriptive paper; therefore, the secondary sources of data have been used mainly for the study. Most of the facets are described with the help of illustrations bring from various sources.

\section{Discussion}

\section{An Unique Search for Expression}

The discovery of a way for humans to express their emotions through signs was a revolutionary change in the development 
and progress of human civilization. One of the initial methods of emotional manifestation through signs was 'Art'.

\section{Prehistoric Art}

The prehistoric period began somewhere late in geological history. Prehistoric art is art emerged in prehistoric and preliterate cultures for expression through signs. This method of expression was generally continued until that cultures had developed either script and writing or other techniques of record keeping. Human artefacts in the Upper Palaeolithic era show earliest evidence of symbolic expression dating back 40,000 years, although it is possible that it was originated earlier (Figure 1) [2].

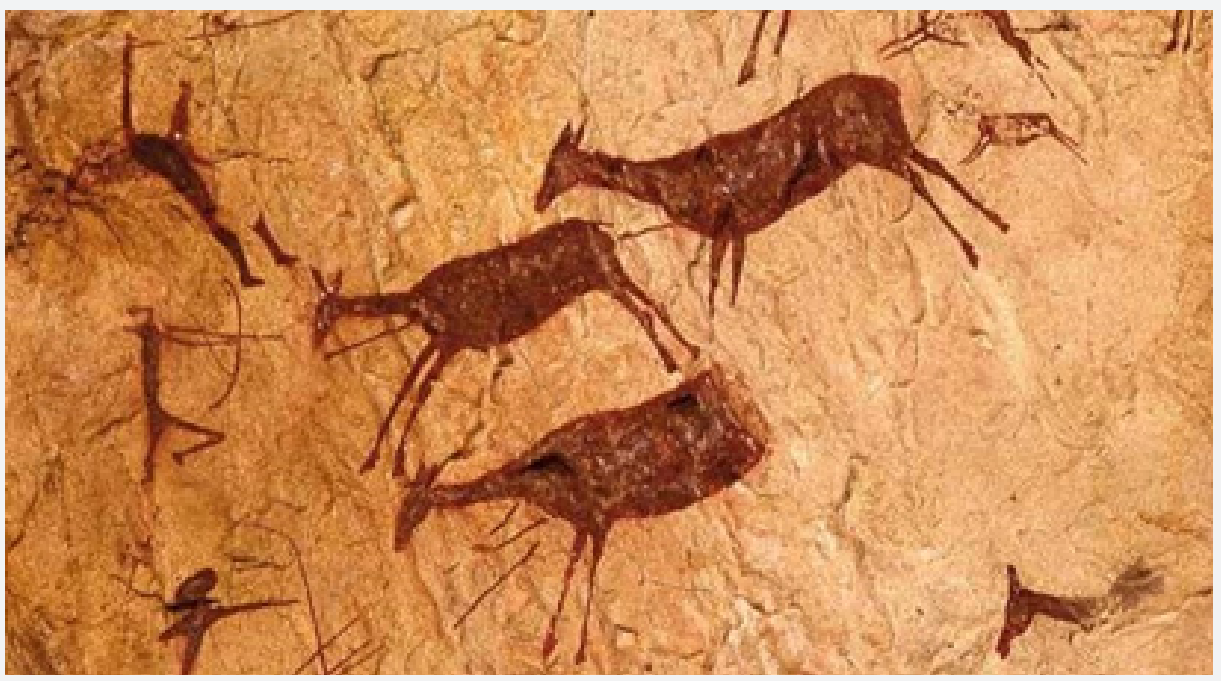

Figure 1: Hunting Scene in Prehistoric Rock Art, Cavalls, Spain [2].

\section{Tally Marks}

Upper Palaeolithic man has left tally marks in the figures on the walls of the cave as evidence of the beginning of writing in the form of symbolic recorded information. Besides, portable sticks crossed hash marks are also found. For instance, a bone tool - 'Ishango bone' is found in the Congo, Belgium. It belongs to the Upper Palaeolithic Age and its time is estimated to be around 18,000 to $20,000 \mathrm{BC}$. This dark brown bone is actually the fibula bone of a baboon. It has a series of tally marks carved in three columns running through the length of the tool (Figure 2) [3].

Figure 2: Ishango Bone with Tally Marks from Belgium, 18,000 to 20,000 BC [3].

\section{Historical Background of Manuscripts}

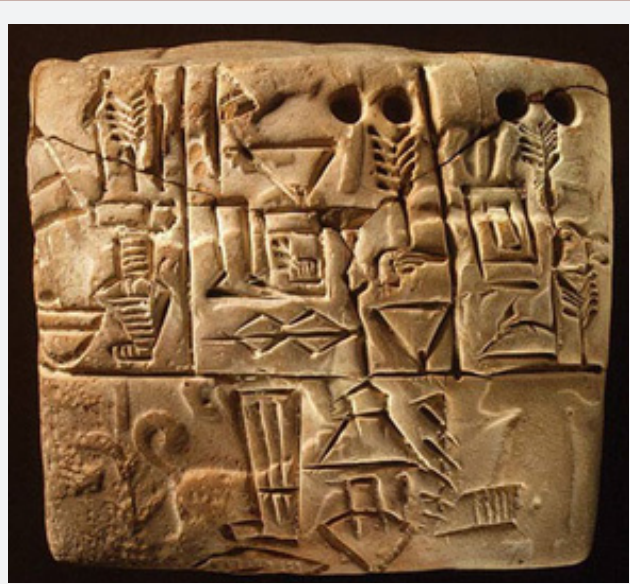

Figure 3: Egyptian Clay Tablet, 3100-2900 BC [4]. 
It is believed that the script was invented in Sumer, southern Mesopotamia, around 3500-3000 BC. To convey information, the people of Sumer, firstly used 'Clay tablets' (Figure 3). The Egyptians initiated using papyrus scrolls by the Early Dynastic Period (31502613 BC) (Figure 4). It was adopted by Greeks and Romans, who further began to use writing tablets of wood. Their wooden tablets were covered with wax (Figure 5). To form a 'Codex', a volume, between wooden or metals covers several wax tablets could be bound together. In the Mediterranean region in $400 \mathrm{AD}$, the papyrus scroll was replaced these tablets [4-6].

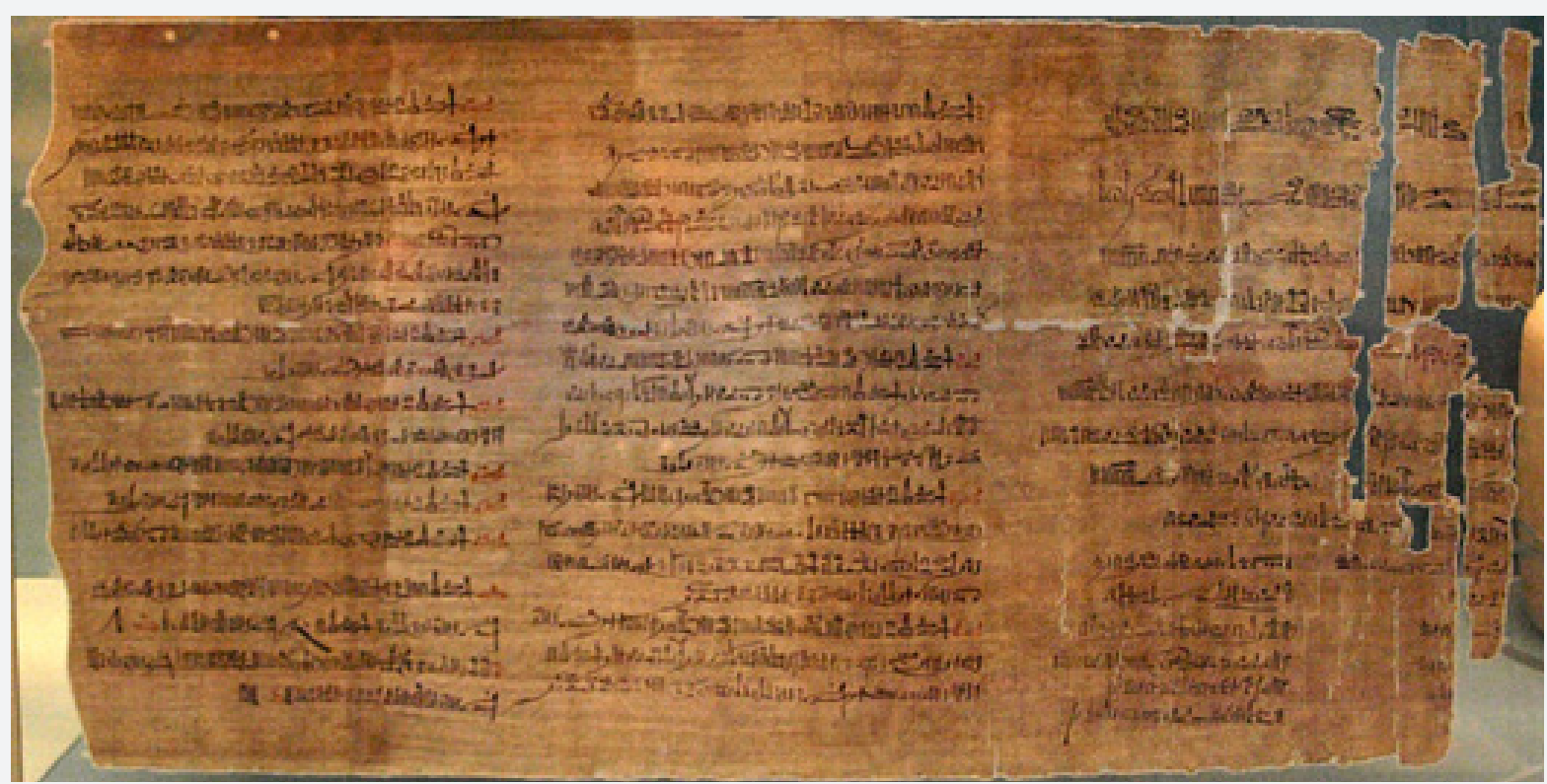

Figure 4: Egyptian Papyrus Manuscript, 1110 BC [5].

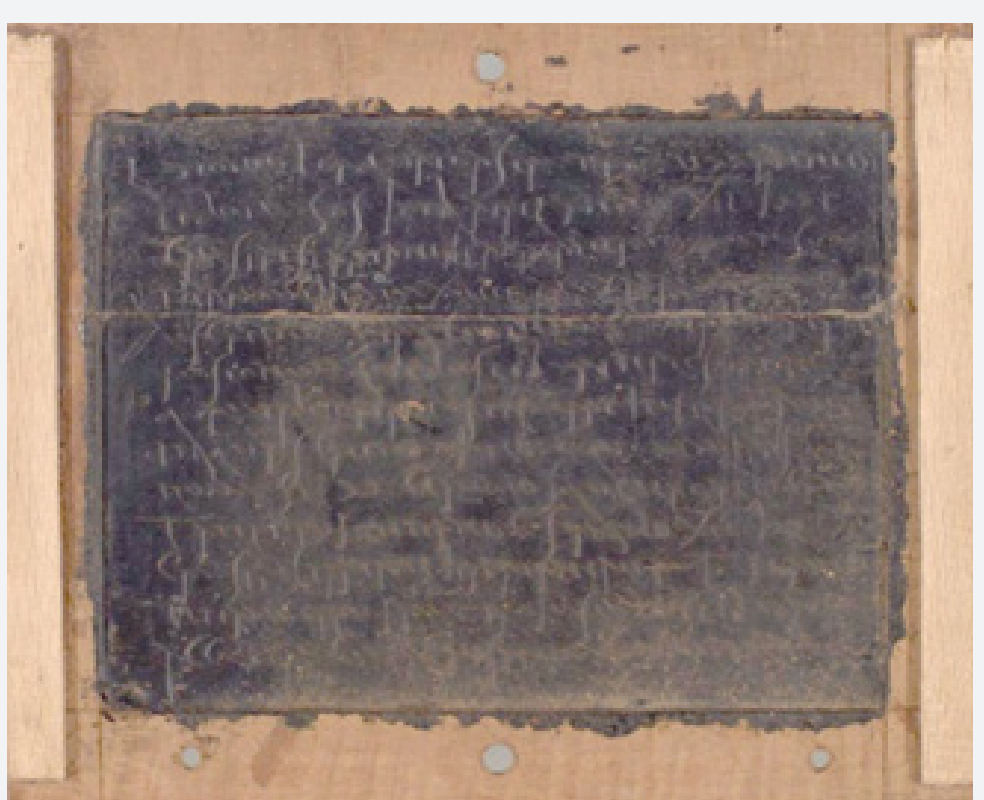

Figure 5: Greek Wax Tablet, 128 AD [6].

During the Han Dynasty in 105 AD, Ts'ai Lun invented 'Paper' in China (Figure 6). In the $7^{\text {th }}$ century $\mathrm{AD}$, Chinese merchants introduced it into the Arab world. The cities of Baghdad and Damascus became important centers of paper and book production. Muslim artisan inscribed illuminated manuscripts as they decorated their books with elaborate borders and illustrations (Figure 7) [7, 8].
However, the recognition of paper was still centuries away in Europe. It was the period of about one century when Chinese were using paper, while people in Asia Minor developed 'Parchment', writing mediums made of animal skins (Figure 8). 'Vellum' was favoured by European monks and it was their customary means for illuminated manuscripts (Figure 9). Thus, Paper would not be accepted by Europeans before $11^{\text {th }}$ century AD [9-11]. 


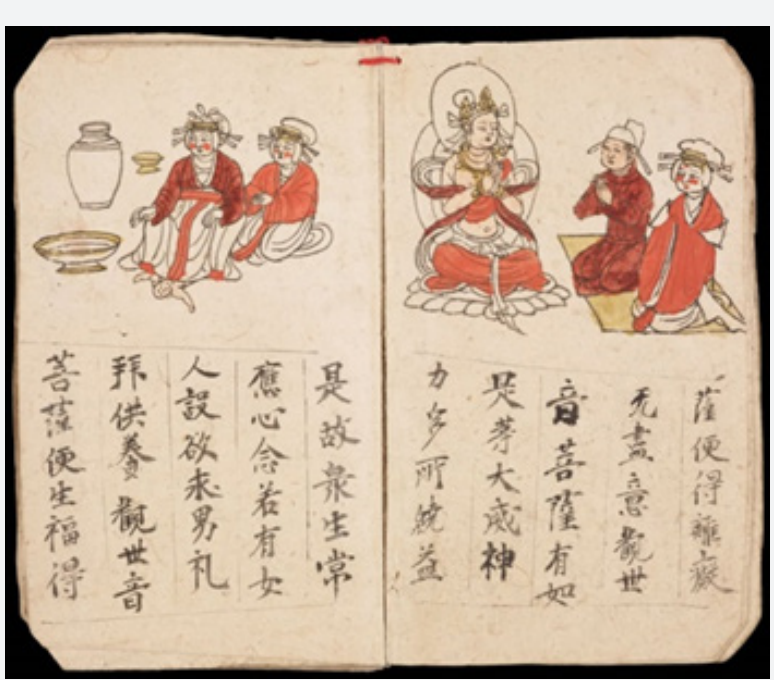

Figure 6: Chinese Manuscript on Paper, Late $9^{\text {th }}$ Century [7].

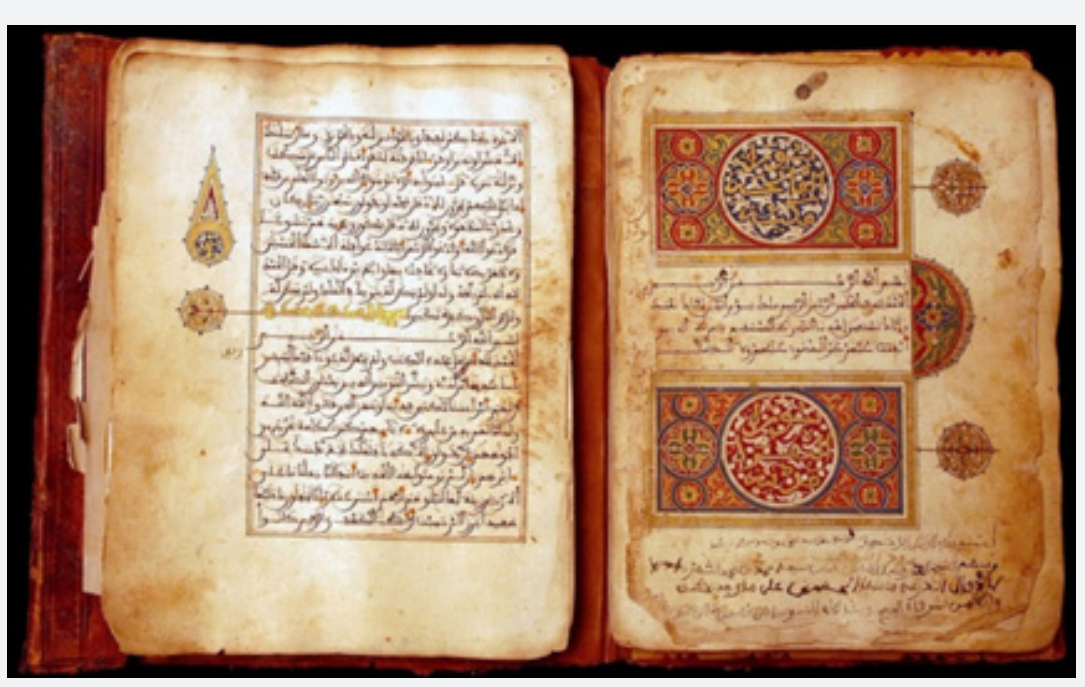

Figure 7: Arab Illuminated Manuscript, $12^{\text {th }}$ Century [8].

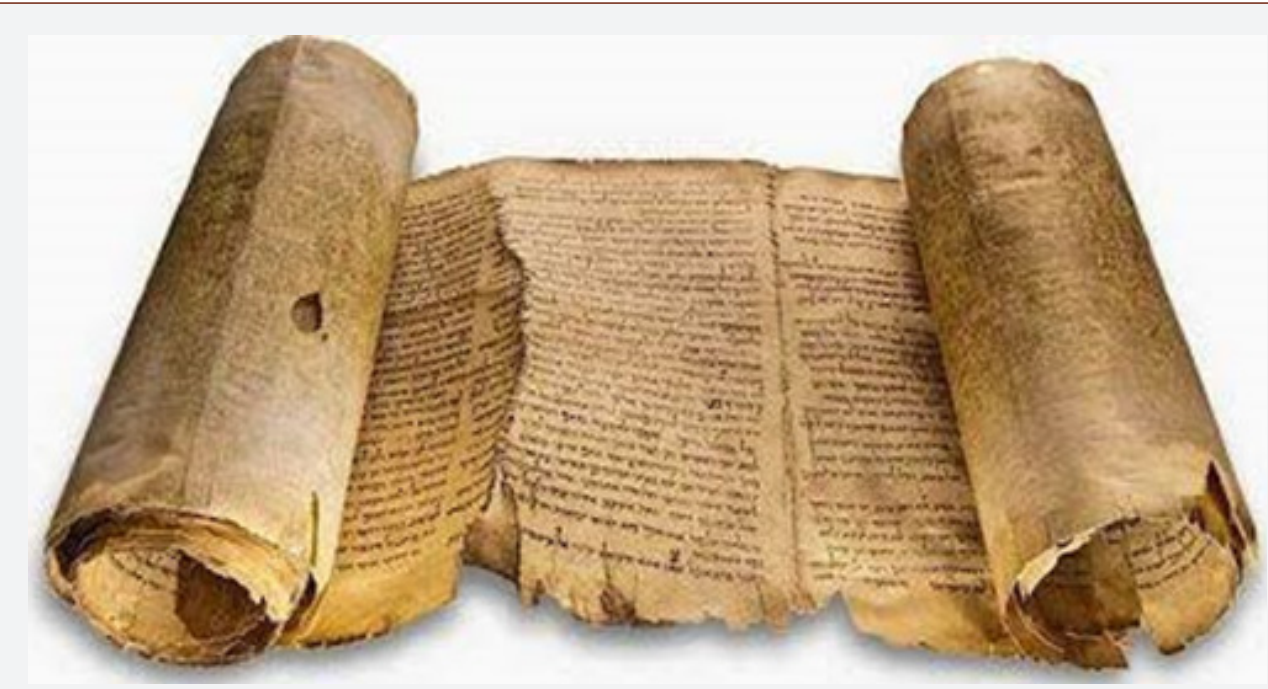

Figure 8: Dead Sea Scroll on Parchment, Qumran Cave, $1^{\text {st }}$ Century BC [10]. 


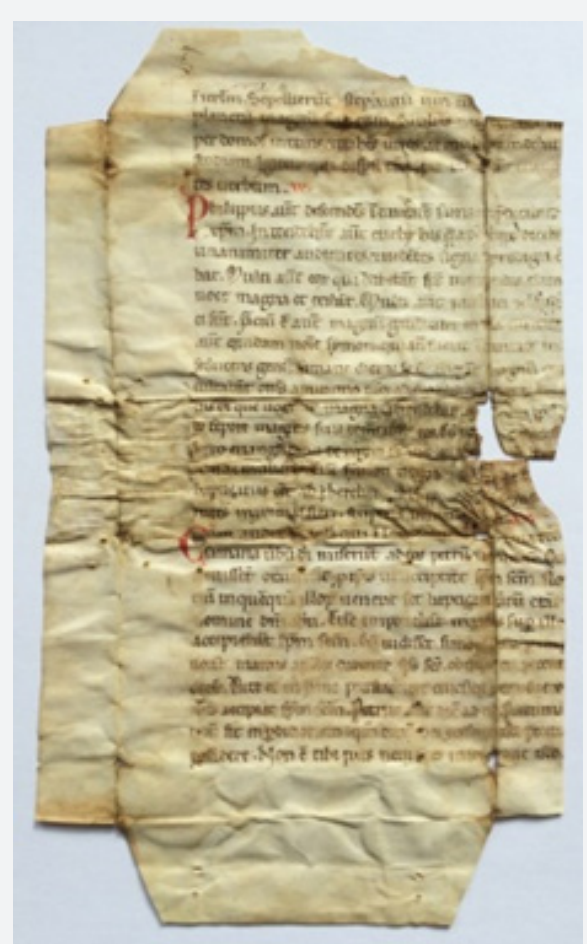

Figure 9: Bible Manuscript on Vellum, France, 1200 AD [11].

\section{Indian Manuscripts}

It is believed that the largest assemblage of manuscripts is of India, which is scattered in all over the world. Indian manuscripts were inscribed or written in a variety of languages and scripts. Variation can also be seen in themes, textures and aesthetics, calligraphies, illuminations and illustrations. The symbolic expression of language in a textual form was originated in India around 4000 BC. It was introduced by Valmiki in his writing 'Ramayana'. 'Vedas' in Vedic, created during 1500 to 500 BC, were some earliest bodies of writings in the world. Around the $4^{\text {th }}$ century, a book in Sanskrit - 'Panniyam' was written by Panini.

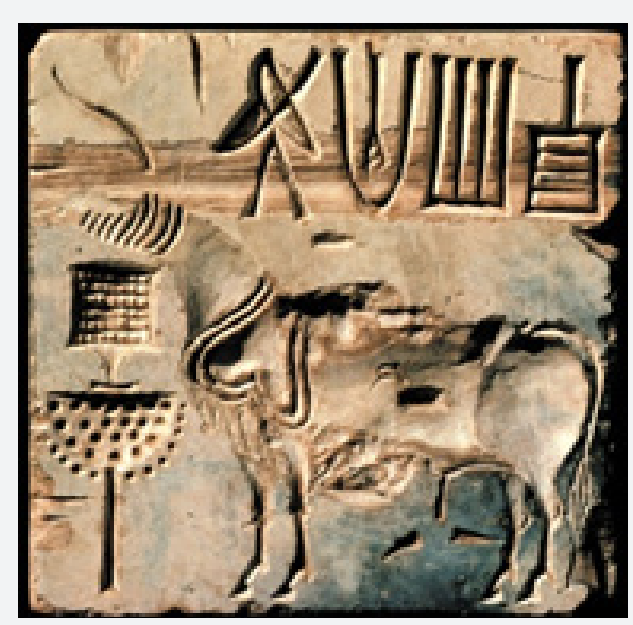

Figure 10: Indus Script on a 4,000 Year Old Sealstone, Mohenjodaro [12].

The initial traces of writing in India are found in the inscription of Indus Valley Civilization which is believed as undeciphered.
Several efforts have been done in this direction and it is claimed by several scholars that they deciphered this script but their work has not yet approved by all, as some recognise their ventures while others reject (Figure 10) [12].

The oldest physical writing in India survives as rock inscriptions. The most famous and earliest inscriptions are those of King Ashoka of the 3rd Century BC who wrote edicts to his subjects in a personal and confessional style. It was written in forms of Prakrit in the Brahmi script (Figure 11) [13].

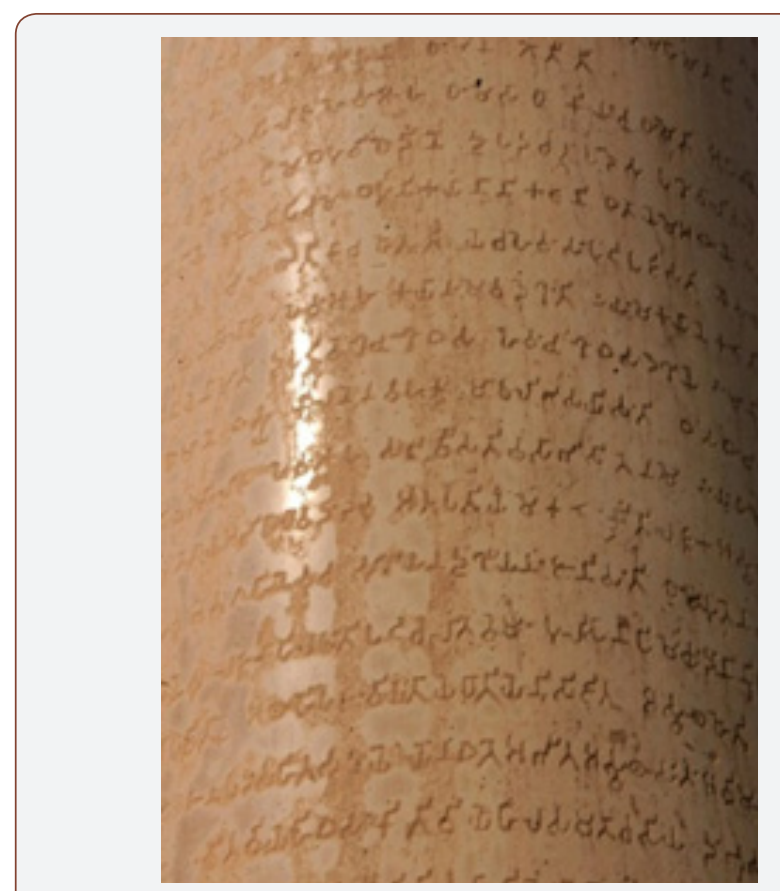

Figure 11: Edicts of Ashoka, Lauriya Araraj, Bihar, 250 BC [13]. 
Over the $1^{\text {st }}$ century $\mathrm{BC}$, the Indian inscriptions become more widespread. These were emerged on the surfaces of cliffs and pillars and stone tablets, drawn on rocks and in caves, some engraved into the bedrock. Further, these were also written on palm leaves (Figure 12), coins, and copper plates (Figure 13) and on walls of the temples. Even in later stages paper was also used to write manuscripts $[14,15]$

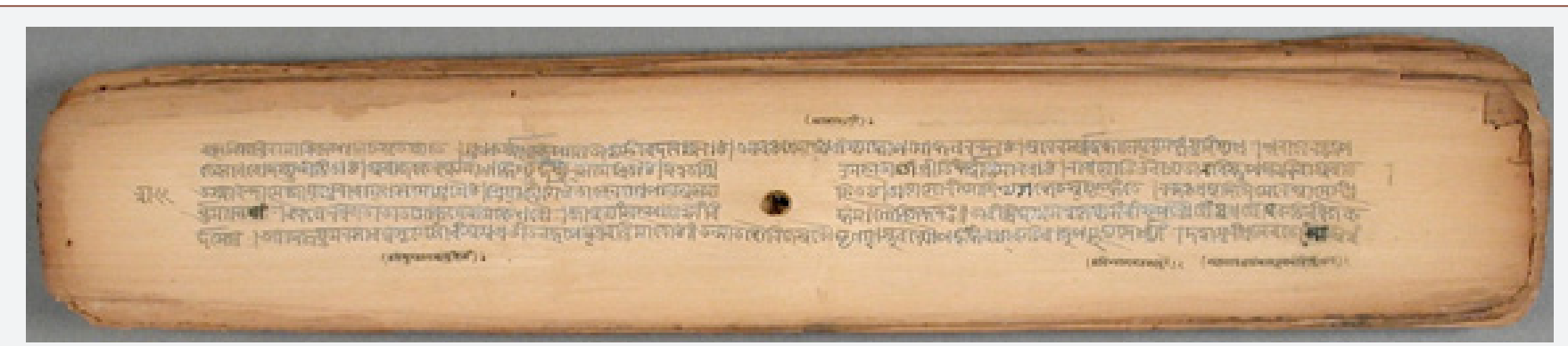

Figure 12: Bhagavata Purana Manuscript on Palm Leaf, $16^{\text {th }}$ Century [14].

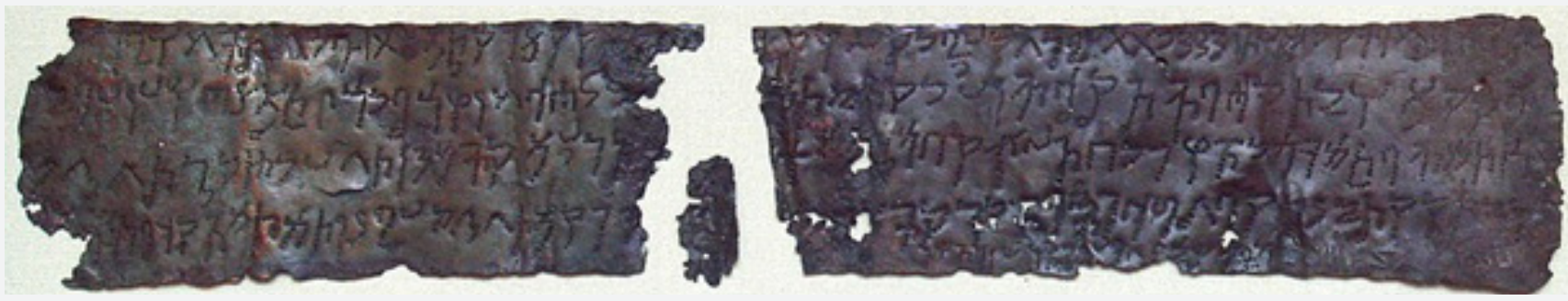

Figure 13: Taxila Copper Plate, $1^{\text {st }}$ Century BC [15].

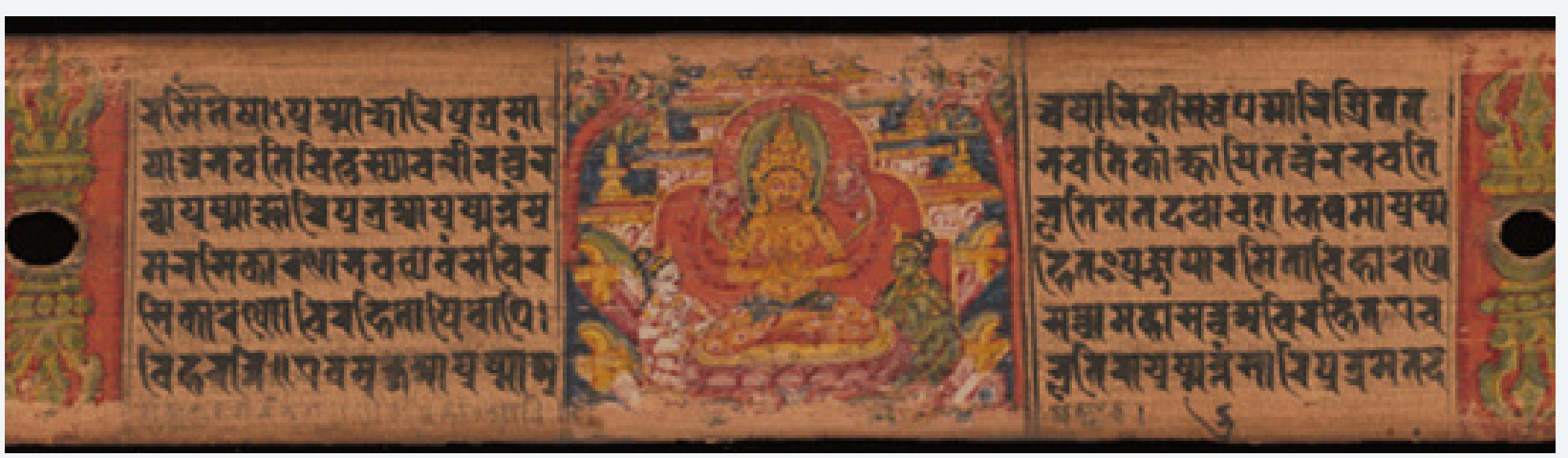

Figure 14: 1,000 Years Old Illuminated Buddhist Manuscript, Kathmandu [17].

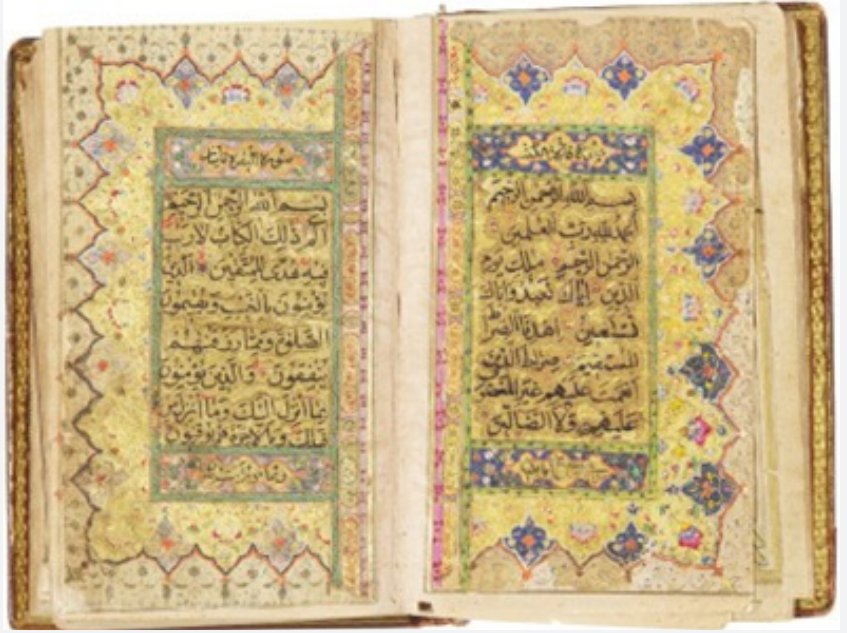

Figure 15: A Miniature Illuminated Qur'an, India, Mughal Period, $17^{\text {th }}$ Century [18]. 
The emergence of practise of illuminated manuscript can be traced in India by $800 \mathrm{AD}$. The traditions of illuminated manuscripts among Jain, Hindu and Buddhist can be seen various regions of India (Figure 14). During the Mughal period, it became the dominant style of producing manuscripts and Akbar was the biggest patron of this tradition in India (Figure 15). This style of manuscript format quickly spread in Hindu dynasties (Figure 16) and the Hindu religious writings like Ramayana, Mahabharata, stories and fairy tales have been written in this format in various languages and scripts [16-19].

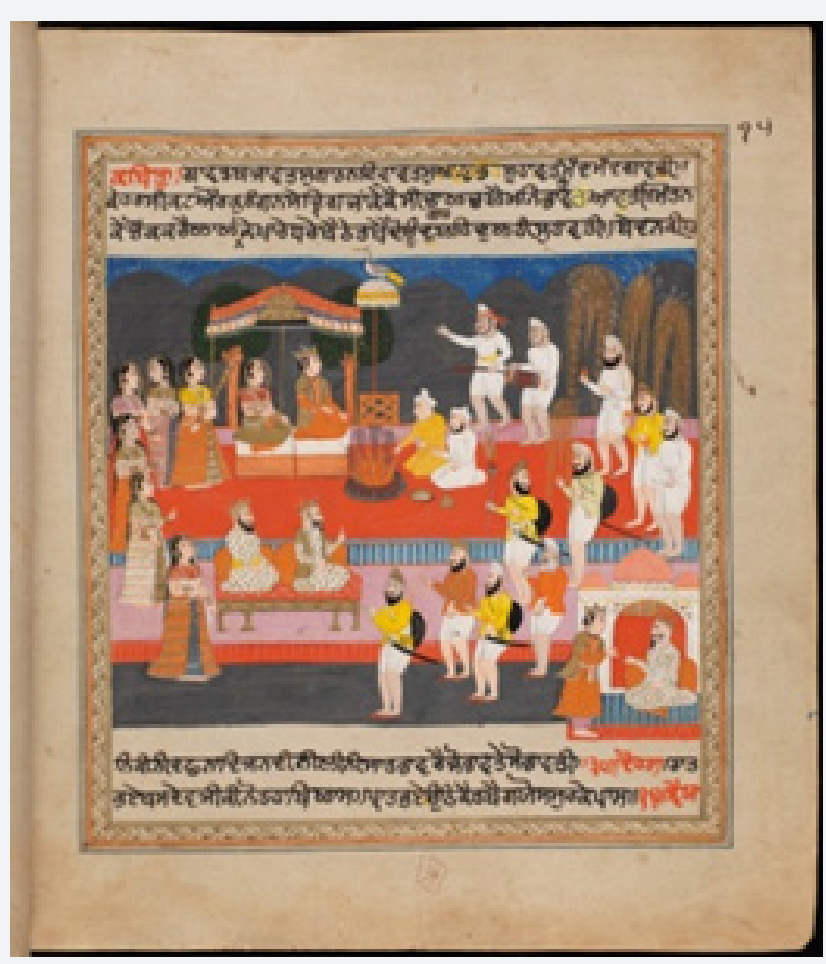

Figure 16: Illuminated Bhāgavatapurāṇa, in Braj Language, in Gurmukhī Script [19].

\section{Medium of Manuscripts}

Since the art of writing was discovered, for the transmission and physical conservation of knowledge across time and space, various materials were used as writing surface. In earliest phase, rock, clay tablet, metal plates etc. were used. Later, these were replaced by softer and tenable parts of the trees such as birch bark, palm leaf, etc. Finally, paper replaced all such materials and it has become a significant part of the human culture and society. Some of the mediums of manuscripts are discussed below:

\section{Stone or Rock}

In early times, people used to engrave or inscribe certain specific information of that time on the rocks, pillars or stones and the walls of caves and temples which were expected to be permanent. On the polished and smooth surface of stone, a skilled artist first scribed the text with ink or dye which was then incised by an engraver using hammer and chisel. Stone is regarded as one of the ancient medium of writing. In India also such stone engraved document is found (Figure 17) [20].

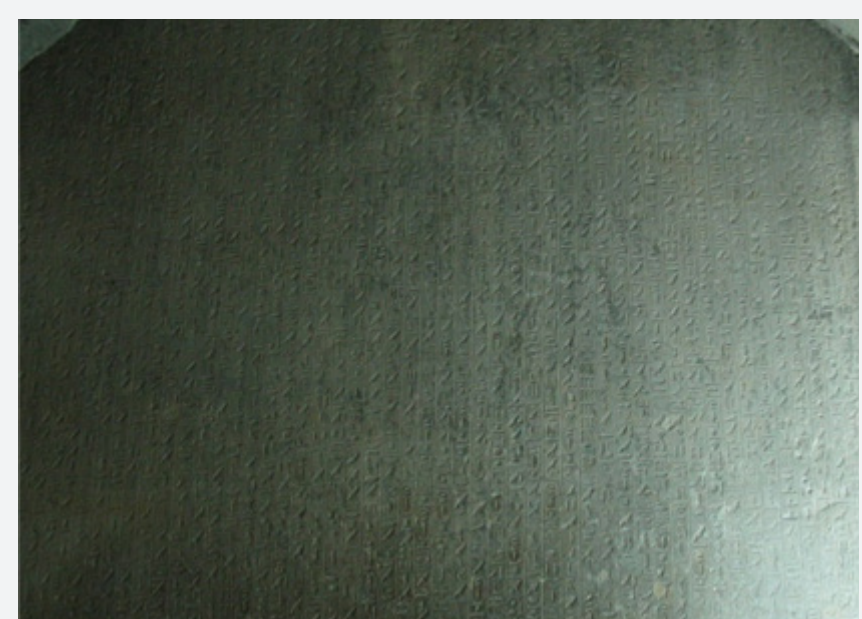

Figure 17: Pyramid Text Inscribed on the Wall of Teti's Pyramid, Saqqara, 23rd Century BC [20]. 


\section{Clay Tablet and Brick}

Since $3100 \mathrm{BC}$, the clay tablet as writing media was first used by the Sumerians of southern Babylonia (Figure 18). Later, this media became the common medium of written communication throughout Mesopotamia and in the entire ancient East. Though the clay tablet or bricks were not the common form of writing materials in India, in some temples it is seen. The evidence of using earthen pots and seals as writing material is also found [21].

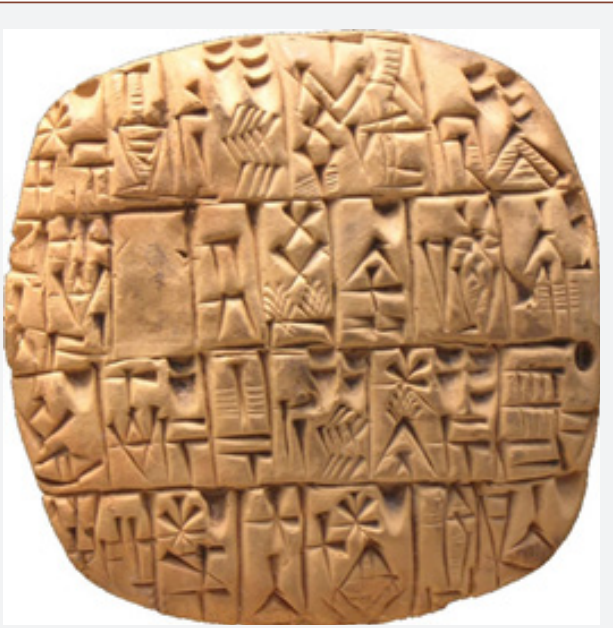

Figure 18: Sumerian Cuneiform on a Clay Tablet, Shuruppak, Iraq, 2500 BC [21].

\section{Earthen Pot, Seal and Coin}

The evidence of using earthen pots, seals and coins as writing material is also found (Figure 19). Generally, the shorter inscriptions are found on these mediums of writing [22].

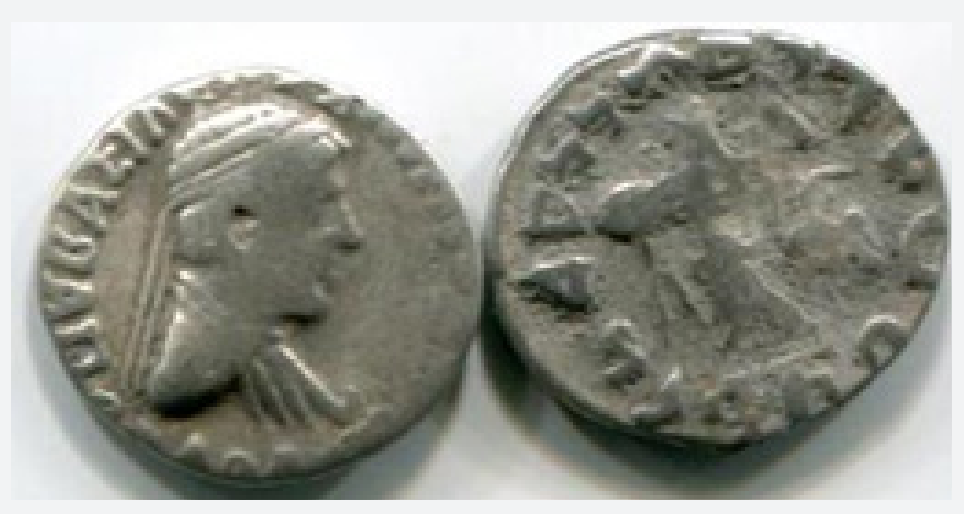

Figure 19: Inscription on Indo-Greek Silver Coin, 80-65 BC [22].

\section{Papyrus}

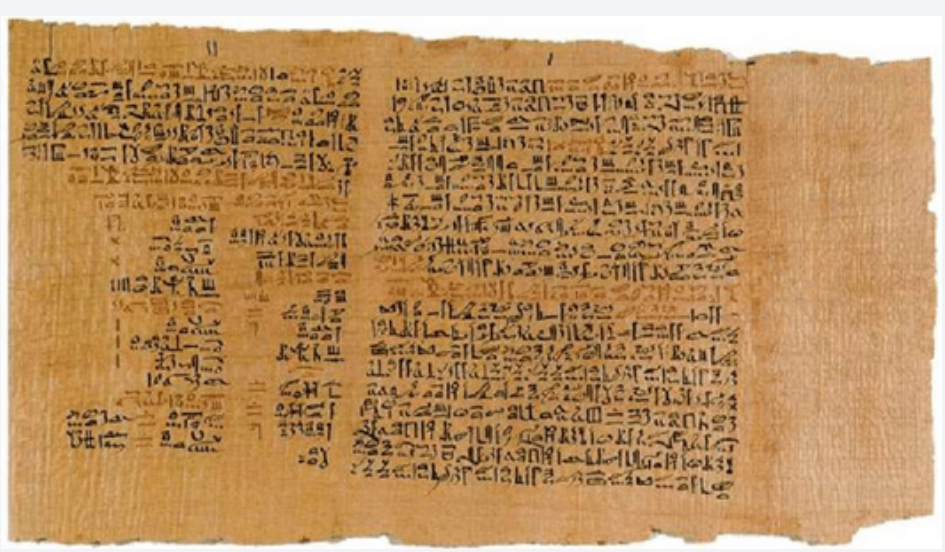

Figure 20: Papyrus Manuscript, Egypt, 1600 BC [23]. 
Papyrus made of the essence of papyrus plant that grows in the marshes and along riverbanks like the Nile. The thick reeds of the papyrus plant were peeled and then cut into thin and flat strips of about $40 \mathrm{~cm}$ long. The thin strips were laid out on boards overlapped to form sheets and were gently beaten with a wooden mallet; and the surface was polished by a pumice stone. When dried, this became a flat and strong writing material which lasted for thousands of years if stored in dry and dark place. In ancient Egypt, around $3000 \mathrm{BC}$, the papyrus was first used as writing material (Figure 20). It was adopted by all over the Mediterranean world in which Greece and Rome were included [23].

\section{Bones}

The oldest Chinese inscriptions on bone were seen around 1200 BC in Anyang which was the capital of the Shang Dynasty. These inscriptions consist of short texts. The script was inscribed on ox scapulae and turtle plastrons. It is known as the 'Oracle bone script' or 'Shell bone script' and was in practice between 1500 and 1000 BC (Figure 21) [24].

Figure 21: Oracle Bone Inscription, 1300 BC [24].

\section{Bamboo and Wooden Strip}

In early China, the strips of bamboo and wood were used as one of the main writing surfaces. These strips were long and narrow in size. Only a single column text was written on each strip. Then strips were bound together in order with cord (Figure 22). This writing medium was used from the 1500 B.C [25].

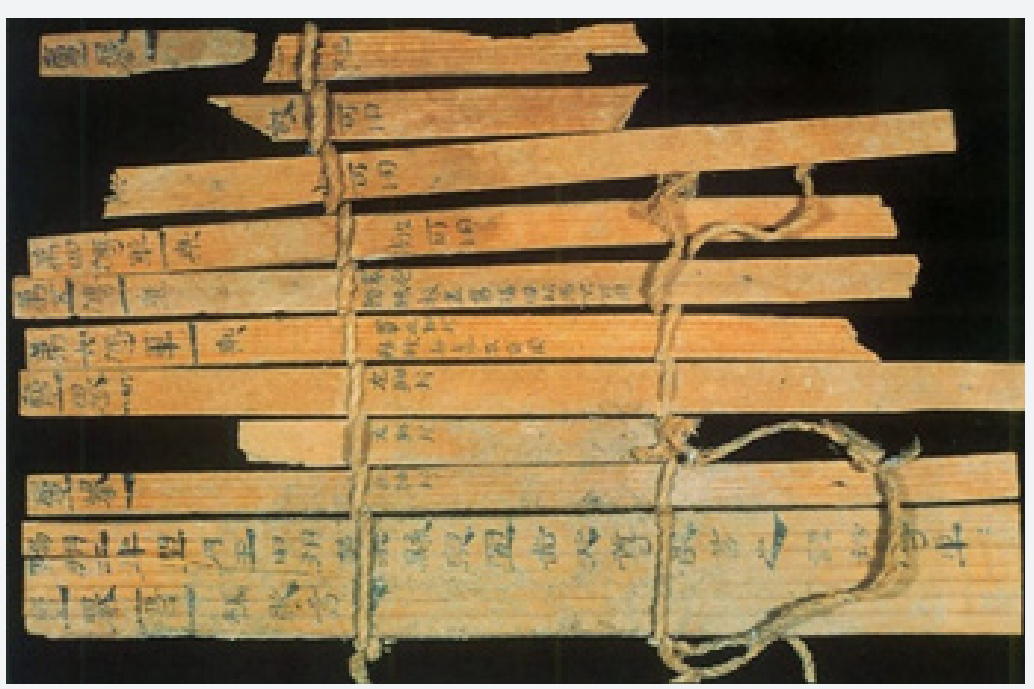

Figure 22: Chinese Manuscript on Bamboo Slips, $5^{\text {th }}$ Century BC [25].

\section{Wooden Board}

Wooden boards as the medium of writing had been in use in
India mainly during the Buddhist age. Generally, these were known as 'Phalak' and were used by the school going children. These boards were mainly made up of sandalwood (Figure 23) [26]. 


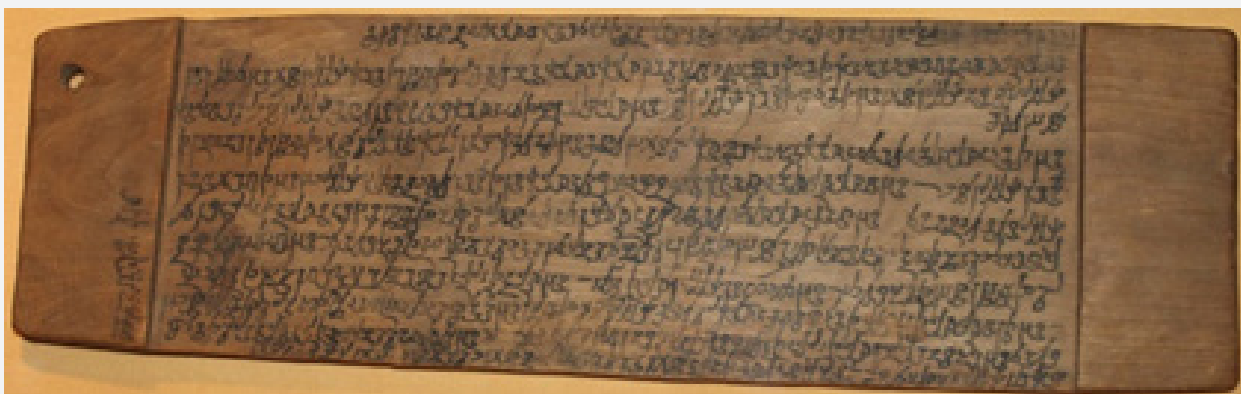

Figure 23: Kharoshti Script on Wood from Niya, $3^{\text {rd }}$ Century AD [26].

\section{Parchment and Vellum}

The parchment and vellum are two different types of writing surface used in the ancient period. Due to shortage of papyrus in Europe, animal skins were also used for writing. Usage of this durable material dates back to 300 B.C. The 'parchment' was a prepared smooth surface for writing made of goatskin and it was reusable
(Figure 24). During the $7^{\text {th }}$ to the $9^{\text {th }}$ centuries, some parchment manuscripts were cleaned through scrubbing for rewriting using milk and oat bran and these reprocessed parchments are known as palimpsests. 'Vellum' was made up of calfskin and most of the improved types of medieval manuscripts were written on vellum (Figure 25). These have significantly higher durability in moist climates $[27,28]$.

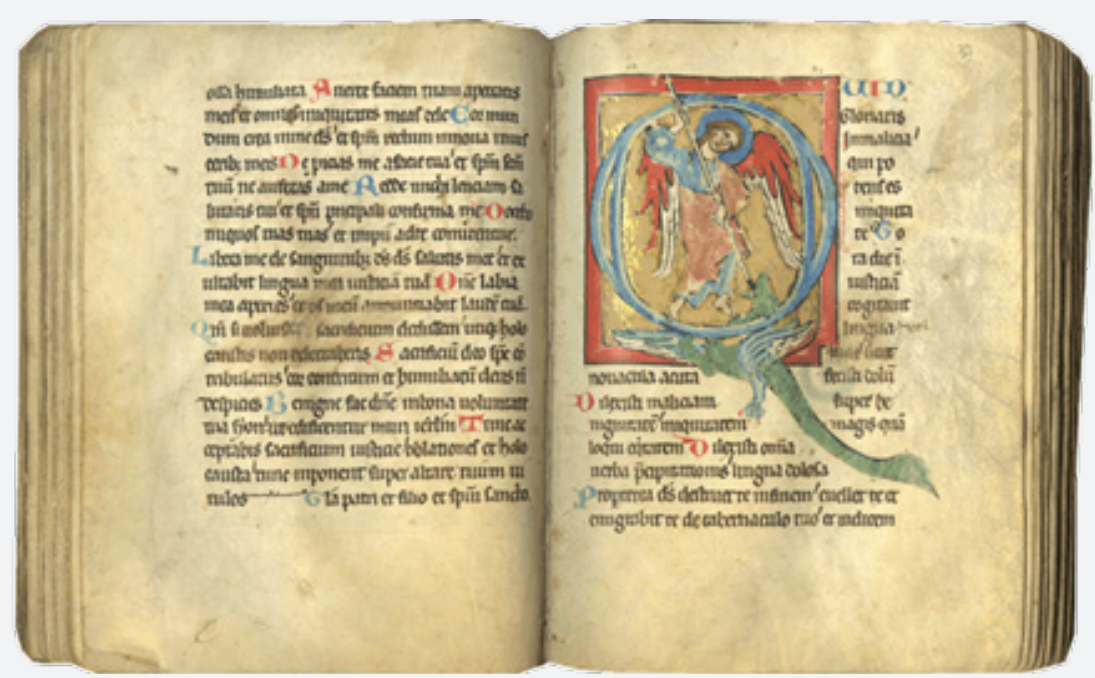

Figure 24: Illuminated Manuscript on Parchment, Southern Germany, 1240-1260 AD [27].

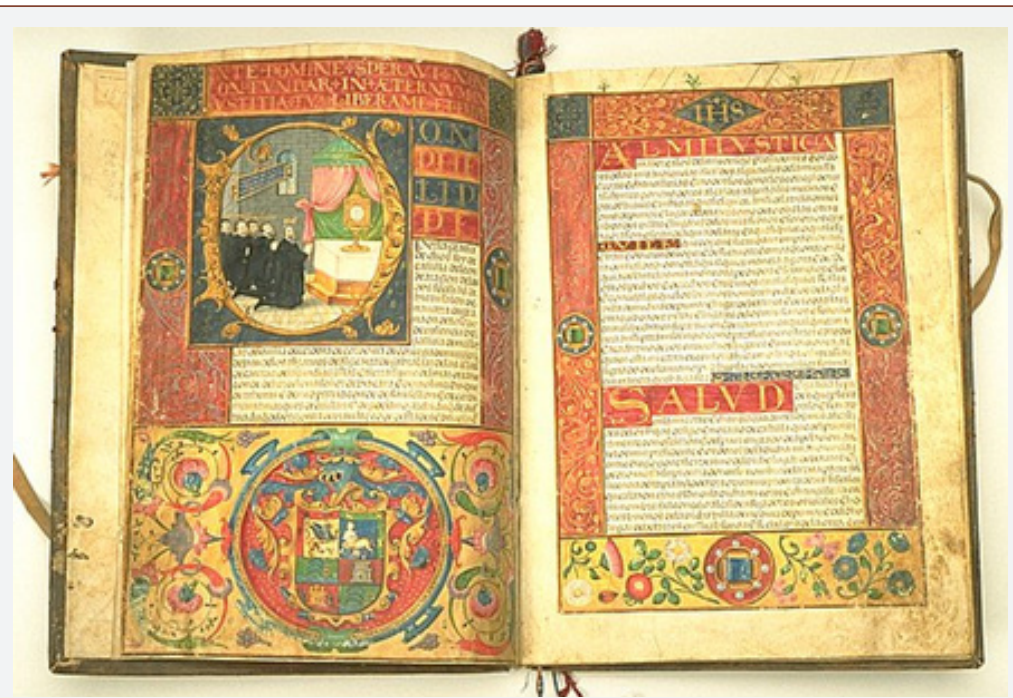

Figure 25: Manuscript on Vellum. Spain, 1563 AD [28]. 


\section{Birch Sheet}

Birch sheets, called 'Bhurja patra' in Sanskrit, are produced from the birch tree. Origin wise, the birch tree is mostly Himalayan. It is a moderate size tree. Inner bark of this tree is very flexible. To prepare for writing, the barks of birch were slowly dried, oil was applied to them and they were polished. These sheets are composed of numerous layers joined together with natural gum and woody knots. Thus, they were prepared fit for to write on with ink. The written leaves of the birch bark were then held together with a string through their middle portion, which was usually left unwritten (Figure 26). Compact book was then fastened to two wooden boards, which not only protected its leaves but also served as its get up. This was used as writing medium since $1^{\text {st }}$ century $A D$, originated in Afghanistan. In India, from the $10^{\text {th }}$ century AD, birchbark was used for the purpose of writing [29].

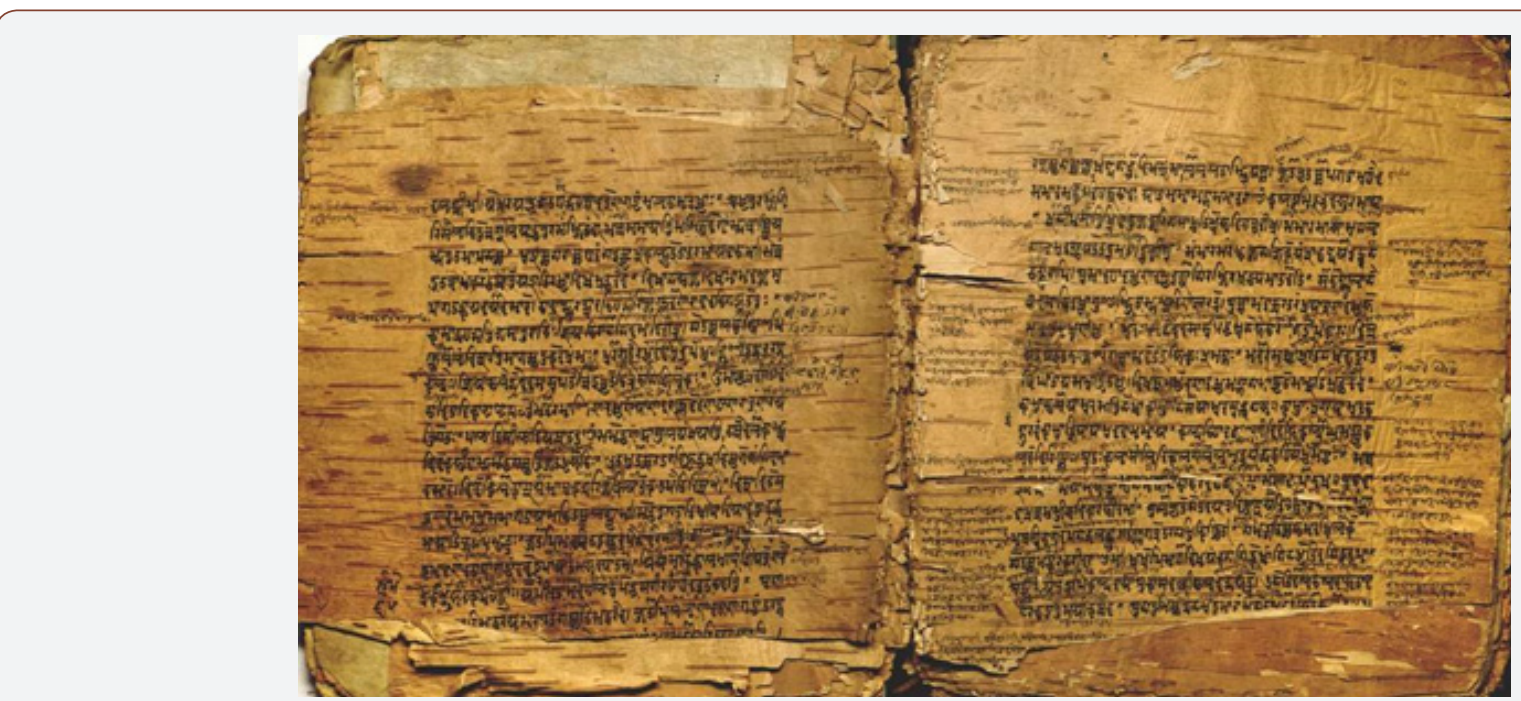

Figure 26: Birch Bark Manuscript, $16^{\text {th }}-17^{\text {th }}$ Century AD [29].

\section{Palm Leaf}

Another writing material used in Sri Lanka, India, Tibet, and other parts of Southeast Asia is 'Palm leaves'. In India, it was mainly used in the southern part and in the states like West Bengal and Odisha. To prepare for writing, Palm leaves were firstly dried and then boiled in water for a few hours. After that these were dried again and polished with a conch-shell or stone. According to need, these prepared leaves were cut into different sizes. Generally these varied from $15 \mathrm{cms}$. to 1 meter in length, while 2 to $10 \mathrm{cms}$. in breadth. Sometimes, two or more leaves were stitched together.
These were of two varieties i.e. 'Tala' and 'Sritala'. 'Tala' leaf is thick and coarse and is tough to handle. It does not absorb writing ink. 'Sritala' leaf is thin, flexible, and beautiful and can be handled like a paper. In the palm leaves, the text was scratched into the surface, and then rubbed with dark colour to make the characters more distinct. In normal environmental conditions it can be preserved for many years, even many centuries. From 200 AD, palm leaf was used as a writing medium and was in continuous use till the $19^{\text {th }}$ century. In India, palm leaf was common writing media until the paper was introduced during $13^{\text {th }}$ century (Figure 27) [30].

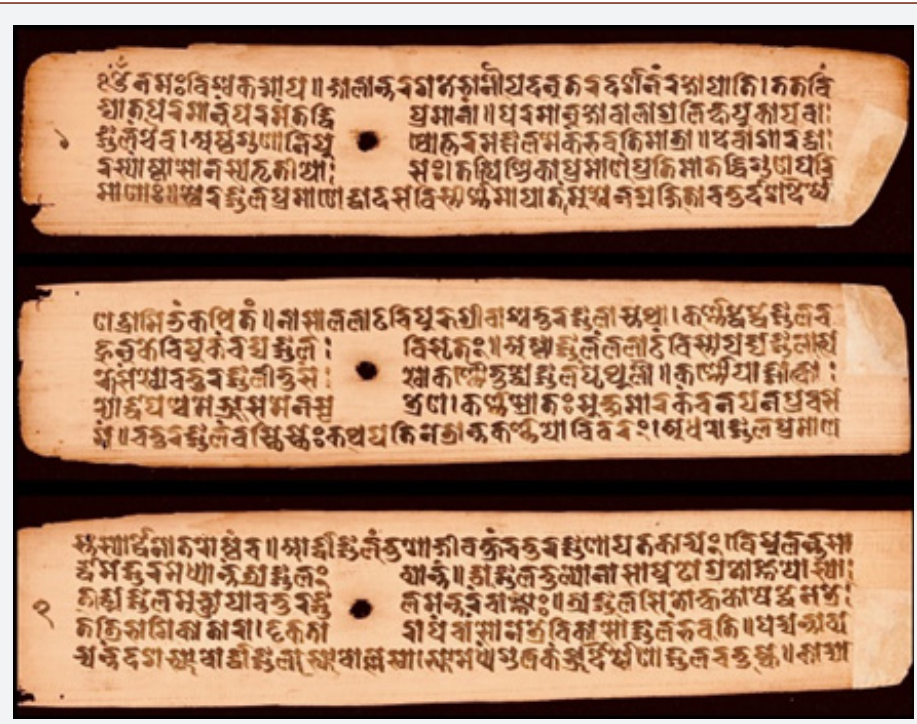

Figure 27: Palm Leaf Manuscript of Brihat Samhita of Varahamihira, 1279 AD [30]. 


\section{Cloth}

In ancient India, cotton cloth, called 'Pata' in Sanskrit, was also used as writing material. The piece of cloth was covered with a thin layer of wheat or rice pulp and then polished with a conch-shell or a smooth stone after the same was dried. Thus, it became usable as writing material. Silk cloth was also utilized as writing medium, mainly in China (Figure 28) [31].

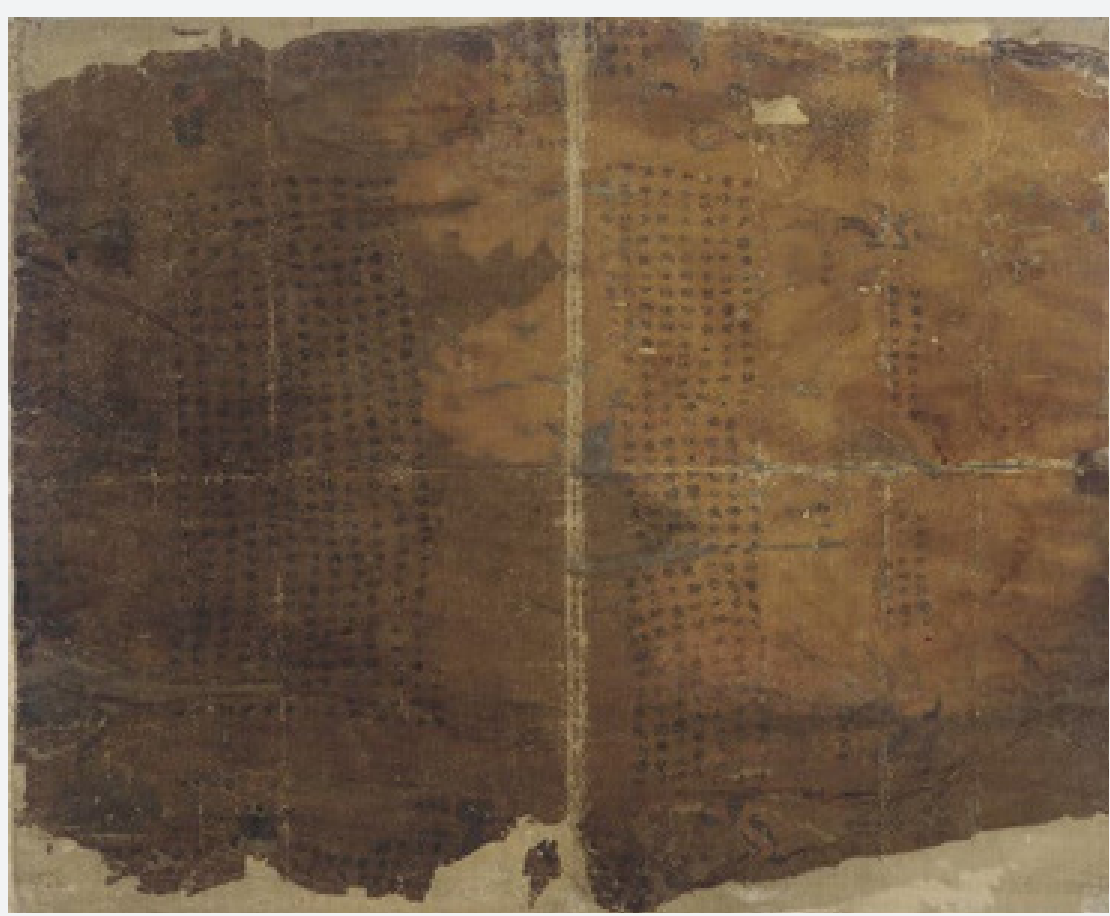

Figure 28: Chinese Chu Silk Manuscript, 475 to $221 \mathrm{BC}$ [31].

\section{Paper}

Paper was developed by the Chinese around 105 AD. Thus, it came into use about 2000 years ago (Figure 29). The paper was firstly prepared through fibre of the hemp plant or the inner bark of the mulberry tree. The Chinese later prepared the pulp from fibres gained from pounding rags, rope, or old fishing nets for paper making. In early stage, Chinese paper was very coarse for writing purpose. Thus, the art of paper making developed in China and later the technology first spread east through Mongolian immigrants and eventually reached Maya in Mexico. In the west it reached Islamic lands from Samarkand and ultimately spread to Europe and America. Besides these, some kinds of metallic plates were utilised for writing purpose especially for some special and important incidents. The various types of plates are:

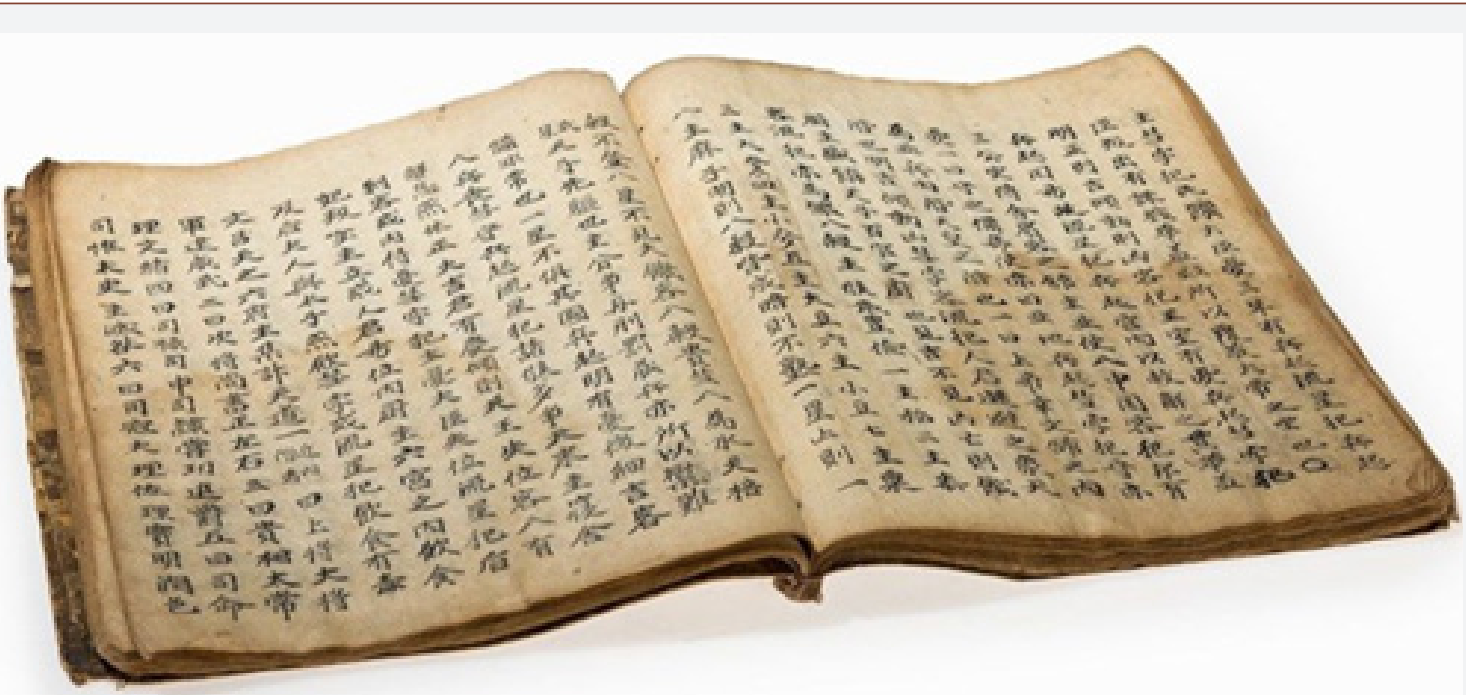

Figure 29: Calligraphy on Paper, China, Qing Dynasty, 1644-1911 AD [32]. 


\section{Gold Plate}

The gold plates were not used on a wide scale, because of its expensive nature, but in some cases, these were used for writing purposes (Figure 30). The important documents like moral maxim, royal letter and land-grants were written on this media [33].

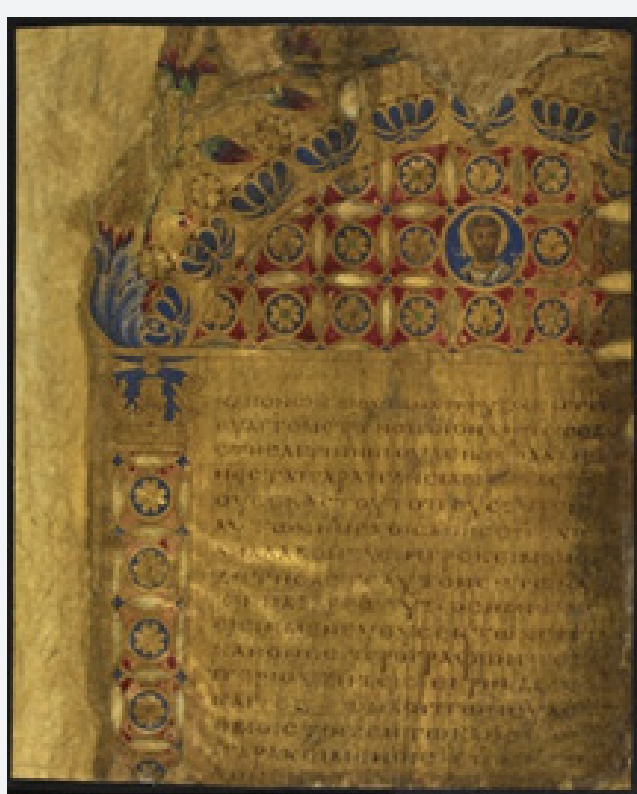

Figure 30: Manuscript on Gold, $12^{\text {th }}$ Century AD [33].

\section{Silver Plate}

Silver though cheaper than gold, was not used as a writing medium in extreme number. Some official documents were inscribed on it. Along with these, certain inscriptions are found on ancient silver amulet (Figure 31) [34].

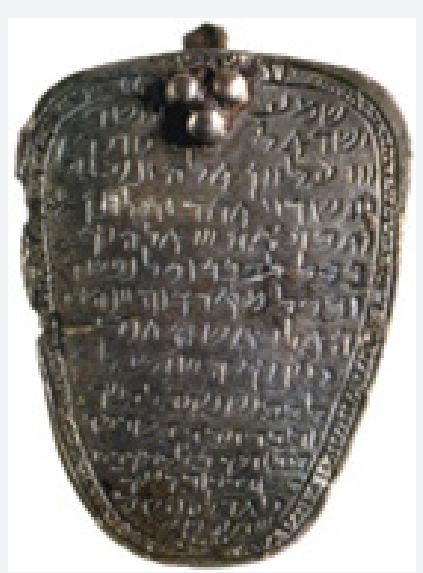

Figure 31: Inscription on Ancient Silver Amulet, Israel [34].

\section{Copper Plate}

The inscribed copper plate is known as 'Tamrapatra'. In ancient and medieval India, copper was the most commonly used material to write on (Figure 32). For making writable, copper pieces were hammered into various shapes and sizes. After the plates were prepared, an expert writer generally wrote on it the body of the text, which was then incised by an expert smith. Sometimes the letters were inscribed in the form of dotted lines with a punch [35].

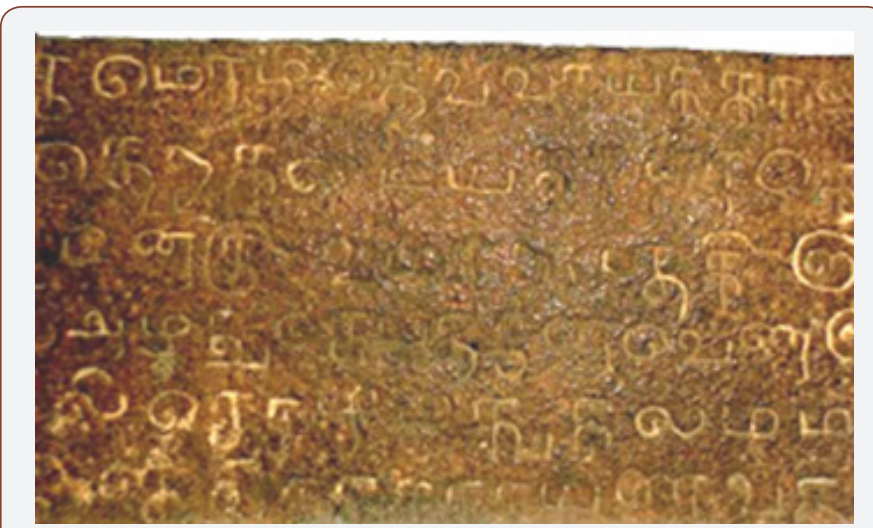

Figure 32: Chola Inscription in Tamil on Copper Plate, $12^{\text {th }}$ Century AD [35].

\section{Brass and Bronze}

Brass and bronze were also used for writing purposes to some extent (Figure 33). The Archaeologists discovered bronze tablets from ancient Roman collections [36].

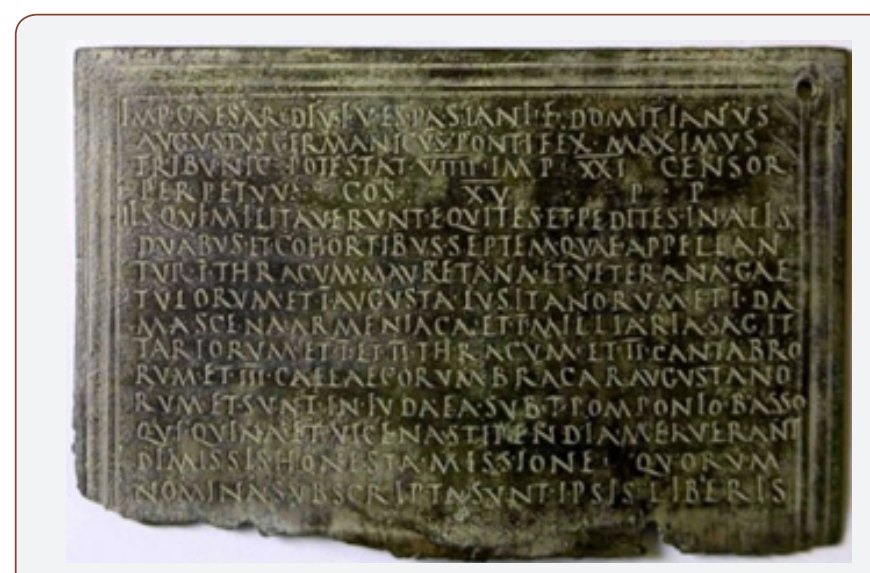

Figure 33: 1,922 Years Old Bronze Inscription, Israel [36]

\section{Tools Used in Writing Manuscripts}

In the ancient time, various tools were used for writing on different mediums.

- Reed stylus is a wiring tool used to inscribe into clay tablets (Figure 34).

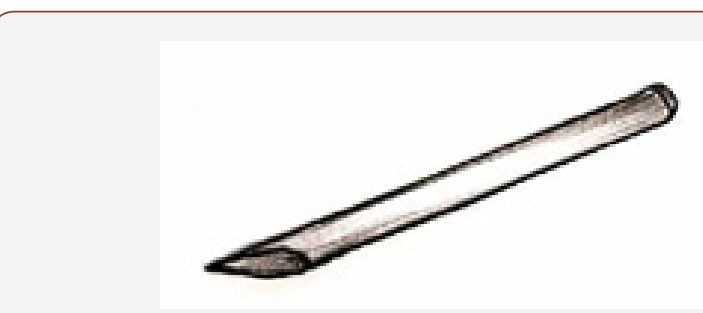

Figure 34: Reed Stylus for Inscription on Clay Tablets. 
- For the rock and other metals, different types and size of hammer, chisel, graver etc. were used to inscribe the script on it (Figure 35) [33,34].

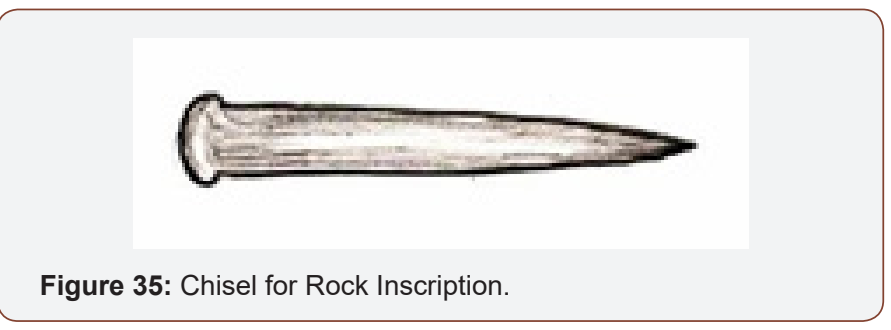

- The brush and pointed knife were used to write or inscribe on wood, bamboo and even flat animal bone (Figure 36). Further, to make it more distinct ink was often used to fill in the inscribed writing.

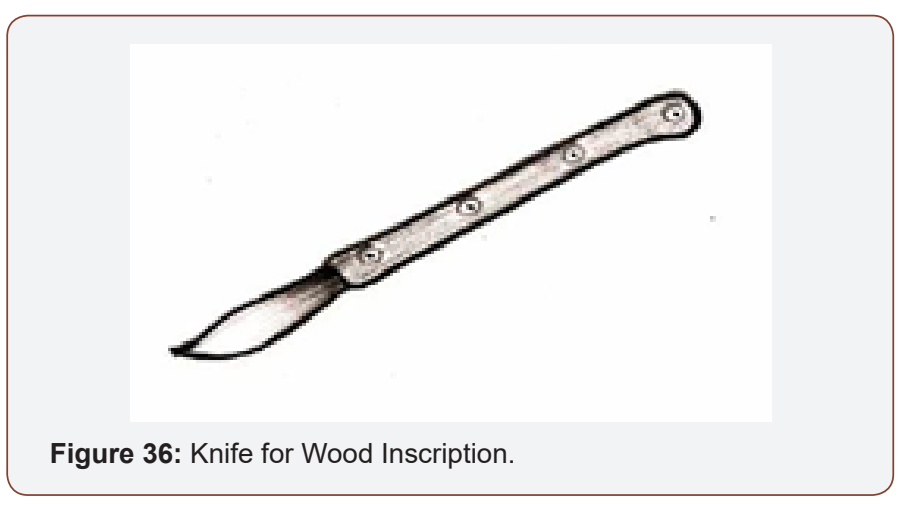

- A bronze made stylus was used to write on palm leaves. One end of stylus was sharp-pointed and was used to inscribe the letters. There was a flat blade on another end to make the surface of the leaf very smooth through scraping (Figure 37).

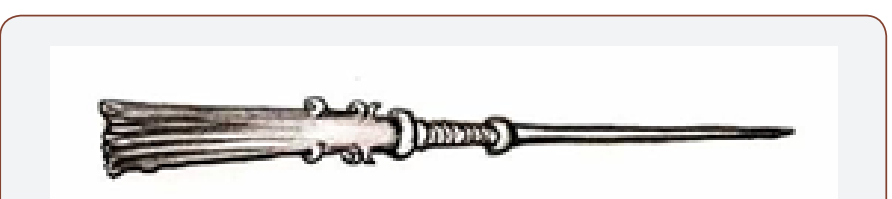

Figure 37: Bronze Stylus for Palm Leaf Inscription.

- A pen like long and thin stylus was used to inscribe on the wax. Its pointed end was used for writing purpose. There was a broad flat part on another end, used for erasing by flattening the wax out (Figure 38).

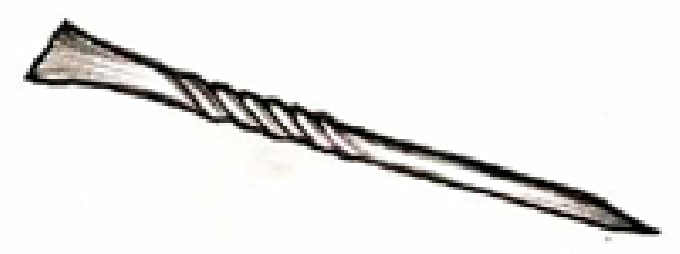

Figure 38: Bronze Stylus for Wax Inscription.
- $\quad$ For writing on papyrus, a special reed pen was used. There was a slit in its pointed end to facilitate the movement of the ink (Figure 39). The pen had to be repeatedly dipped in ink for writing, but this functioned good enough.

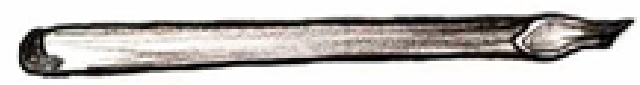

Figure 39: Reed Stylus for Papyrus Writing.

- A bone stylus with metal tip or a thin piece of lead known as 'plummet' was used to inscribe on the parchment and vellum (Figure 40). Various types of pens were used for writing on this medium which included reed pens, and quill pens made up of flight feathers of large birds (Figure 41).

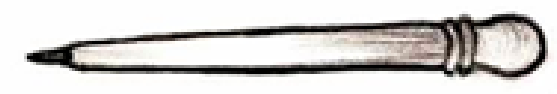

Figure 40: Metal Tipped Bone Stylus for Parchment and Vellum Inscription.

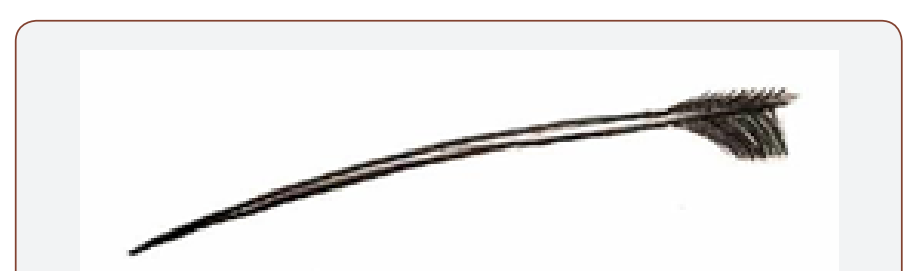

Figure 41: Feather Quill for Writing on Parchment and Vellum.

- For writing on paper, brush was also used as writing tool. These brushes were thick, while tapered to a fine point (Figure 42).

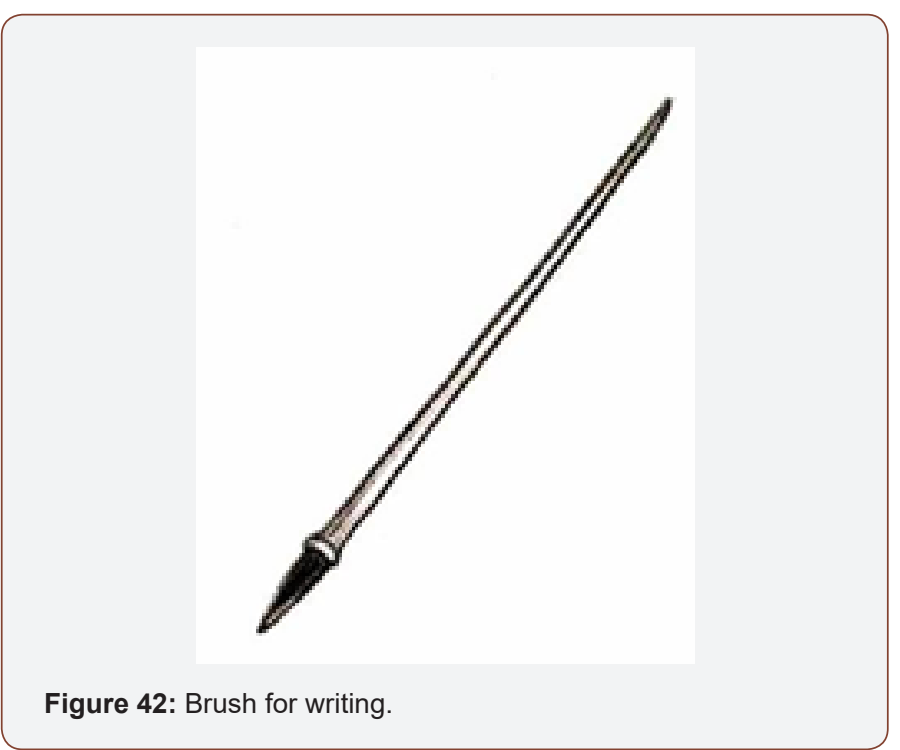




\section{Damages of Manuscripts and their Causes}

Though deterioration is a continuous and natural process, there are some root causes behind this deterioration of the valuable manuscripts:

\section{Internal Cause}

The writing materials used in manuscripts are mainly of natural organic. Because of the difficulties for maintaining normal and congenial environmental conditions, these materials automatically become fragile. If the material is of poor quality, the natural decay or aging will be faster.

\section{External Cause}

The external deterioration of the writing materials is caused by the atmospheric and environmental factors including various agents like physical agent (heat, light, darkness, flood, fire and earthquake etc.), biological agent (fungus, bacteria, insect, silverfish, book lice, cockroach, mice and rats etc.), chemical agent (humidity, moisture, dust and dirt etc.) and human factor (negligence, mishandling, superstitious beliefs and destructive tendency etc.) (Figure 43) [37].

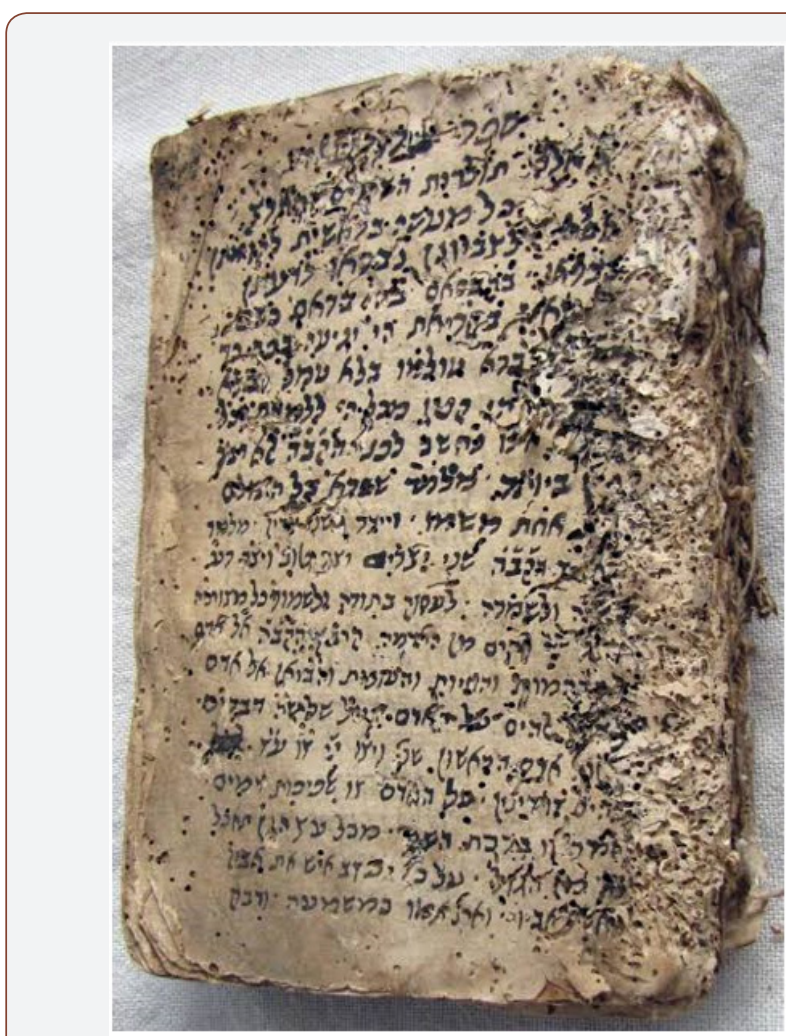

Figure 43: Damaged Jewish Manuscript of $18^{\text {th }}-19^{\text {th }}$ Century [37].

\section{Manuscripts and their Conservation}

Conservation of the manuscripts means the systematic actions taken on a damaged or undamaged manuscript for increasing their lifespan. It aims to keep the objects close to their original condition as far as possible. Its prime objective is to ensure the availability of information on manuscripts in usable form for as long as possible. Its methods are:

\section{Preventive Conservation}

It ensures reduction in deteriorating rate of manuscripts and prolongs the usable life of a manuscript. It is generally applied to undamaged manuscripts. For the preventive measure, the main steps are - maintaining proper storage area, controlling of temperature and humidity, controlling of sufficient light, controlling of air pollution, protection from dirt and dust, and protection against insects and fungi.

\section{Curative Conservation}

Curative conservation mainly acts for the restoration of damaged manuscripts. Curative measure makes the damaged material reusable. Some of the curative measures used for the manuscript conservation are cleaning, repairing, fumigation and lamination (Figure 44) [38].

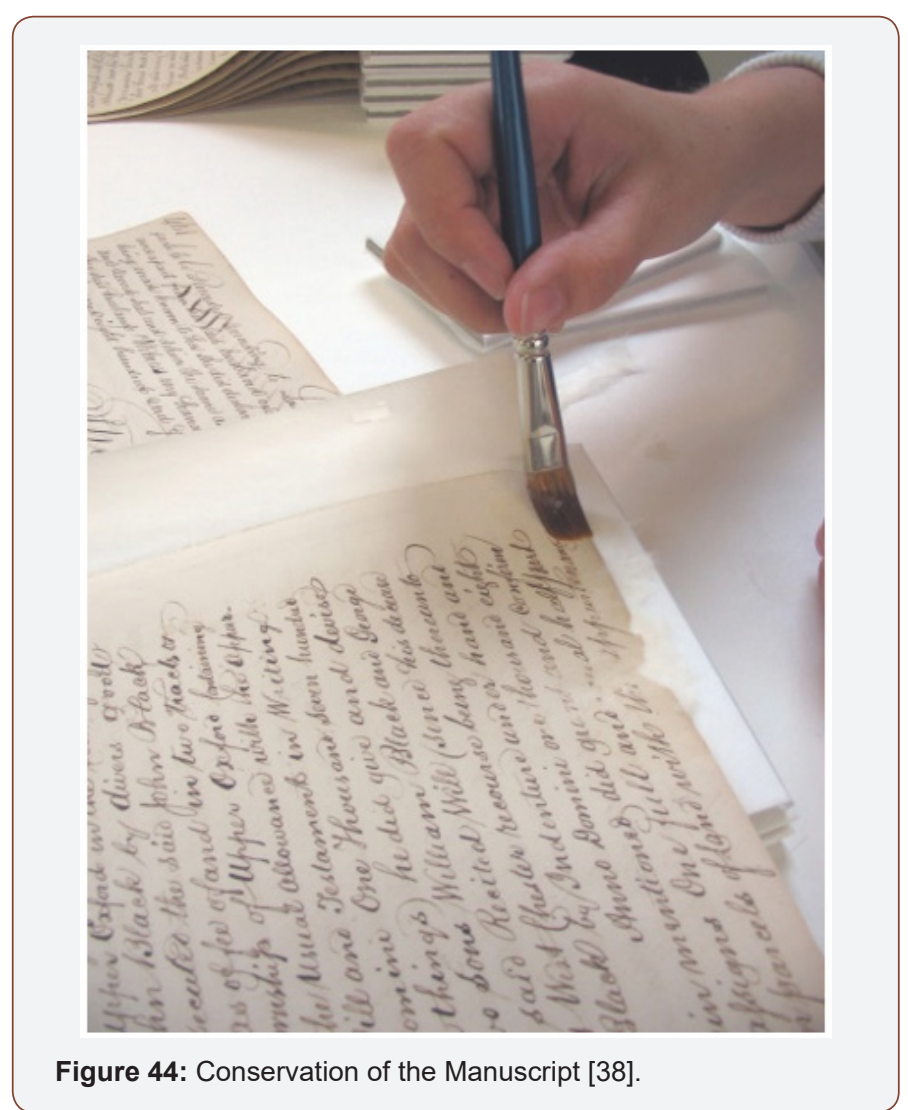

\section{Impact of Information and Communication Technology on Manuscript Conservation}

Now the modern science and technology has influenced on the conservation of the manuscript collection also. The techniques microfilming and digitization of manuscripts are developed as the method of manuscript conservation (Figure 45) [39].

\section{Problems of Conservation of Manuscripts}

There are different problems raised in the process of manuscript conservation. Some of these are lack of trained manpower, lack of awareness about the importance of rare manuscripts among the custodians of such collection, religious and superstitious belief, 
non-availability as well as high cost of medicines and tools used in the preservation process of manuscripts, lack of cooperation and coordination among the institutions having such manuscripts, and lack of sufficient funding for maintenance and preservation of manuscripts.

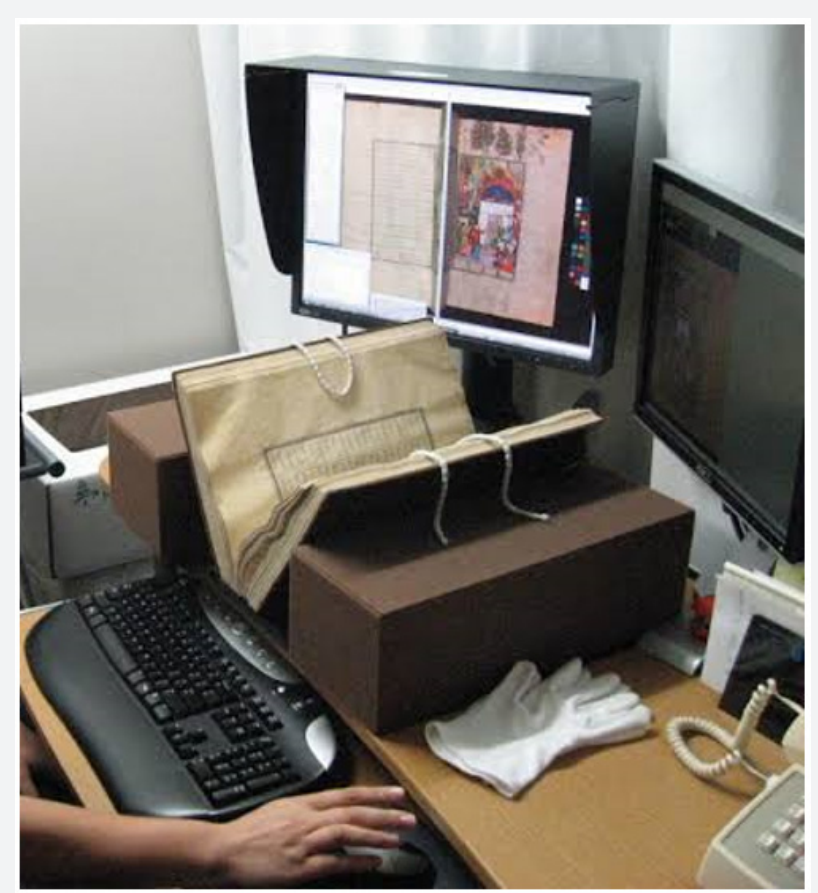

Figure 45: Digitization of Manuscript [39].

\section{Management of Manuscripts}

Manuscript collection is generally treated as archival documents and is kept in a special separate section or archival section of the organization. Management of manuscript collection is a very vital aspect which includes acquisition, accessioning, classification, cataloguing, display, space planning, systematic arrangement, maintenance, and proper usage of manuscripts (Figure 46).

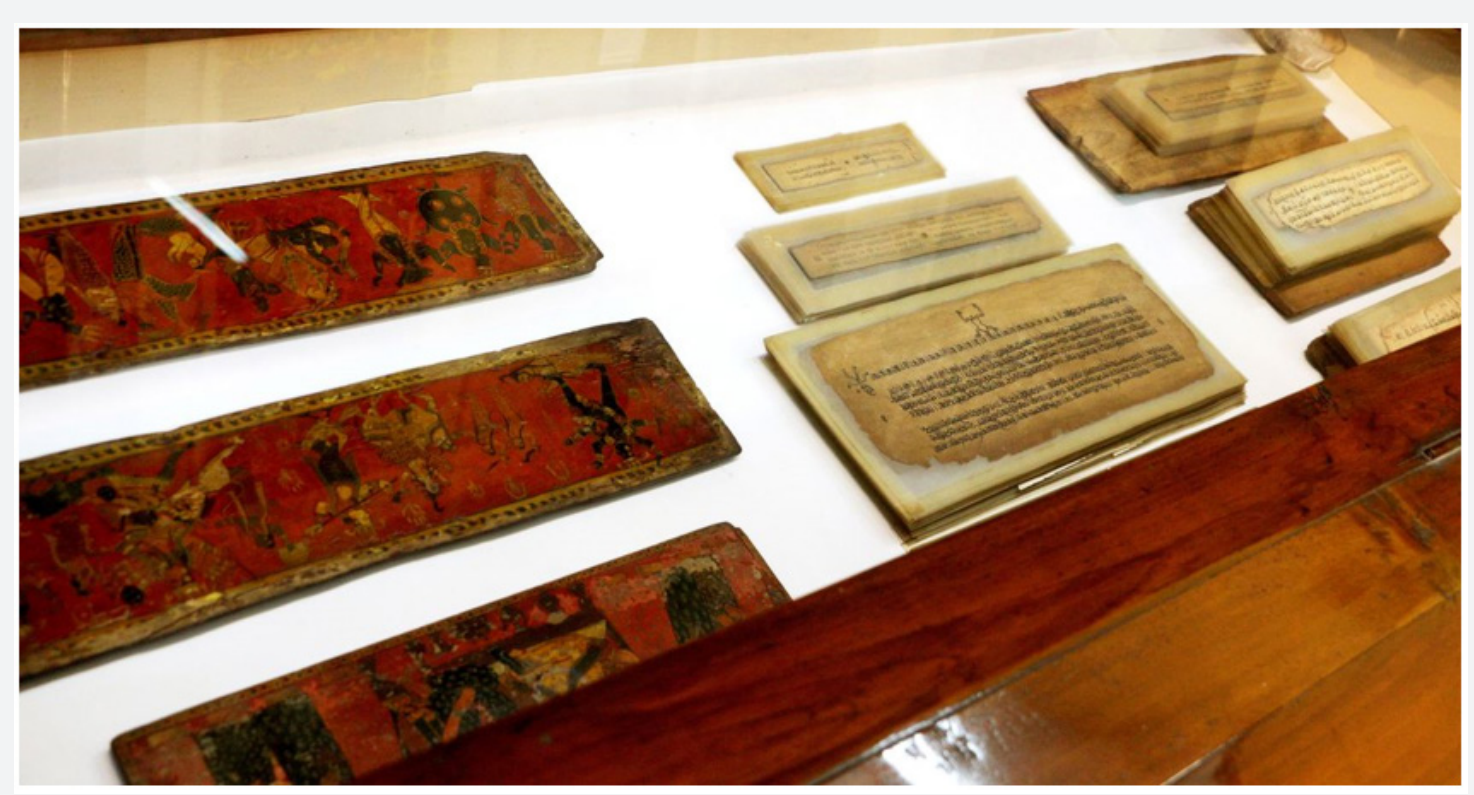

Figure 46: Museum Display of Manuscript [41].

Descriptively speaking, management of the manuscripts deals with collection development, processing, maintenance and access to the collection to the respected users. Its basic objective is to make the collection available for continuing research use without hampering its conservation issues $[40,41]$.

\section{Conclusion}

The beginning of a writing tradition brought a major change to the human civilization. Manuscript is a medium through which the art and culture of our past civilization are transmitted to the present. 
These manuscripts are preserved in different libraries, academic institutions, museums, religious institutions and likewise in private collections of different corners of the globe. The manuscripts available in different forms reflect the background of the cultural heritage of a nation. Due to different factors manuscripts are now in a very vulnerable condition. These available manuscripts are tried to preserve and make them accessible as far as possible. Different institutions and experts have been have appointed for this purpose. For instance, Government of India has started a nationwide mission called the 'National Mission for Manuscripts' which has been working as an apex body in India for conservation and management of the manuscripts scattered in every nook and corner of the nation. It is required that every resident of all the nations should feel his/ her duty to preserve this precious heritage and it is only possible through making general awareness regarding significance of the explicit knowledge of our ancestors -' Manuscript'.

\section{Acknowledgement}

None.

\section{Conflict of Interest}

No conflict of interest.

\section{References}

1. National Mission for Manuscripts. (2016) What is Manuscript?.

2. Spain is Culture. Rock art of the Mediterranean Basin on the Iberian Peninsula: Prehistoric Painters.

3. The Ancients: The Artifacts (2001-2015) Ishango Bone.

4. Historywiz: The Invention of Writing Sumerian Cuneiform.

5. Wikiwand Ancient Egyptian Literature.

6. (2020) Library - University of Michigan. Ancient Writing Materials: Wax Tablets. USA.

7. (2020) Conference at Princeton University. Prospects for the Study of Dunhuang Manuscripts: The Next 20 Years.

8. Reitman, M (2016) One Man Helped Save Over 300,000 Ancient Manuscripts from Islamic Militants. Insidehook, History.

9. Mark JJ (2018) Illuminated Manuscripts. Ancient History Encyclopedia.

10. Interfaith Council of Contra Costa County. (2012-2016) What do the Dead Sea Scrolls tell us about the Bible.

11. Mackus Company (2013) Leaf from a Bible.

12. Robinson A (2015) Ancient Civilization: Cracking the Indus Script, Nature 526: 499-501.

13. Wikipedia. (2020) Edicts of Ashoka.

14. Pinterest $16^{\text {th }}$-Century Hindu Bhagavata Purana on Palm Leaf Manuscript.
15. Academic. (2000-2020) Taxila Copper Plate.

16. University of Cambridge (2015) The 1,000-Year-Old Manuscript and the Stories it Tells.

17. Shotheby's (2020) A Miniature Illuminated Qur'an, India, Mughal, 17th Century.

18. Shankar S (2015) Illuminated Manuscripts of India - With Special Reference to Moghul Manuscript, International Journal of Academic Research 2(3): 90-93.

19. Fondation Martin Bodmer (2018) Bhāgavatapurāṇa, book 10.

20. Revolvy (2019) Pyramid Texts.

21. Wikimedia (2013) Sumerian Account of Silver for the Govenor.

22. Joel Anderson: Interesting World Coins and Paper Money. Ancient \& Medieval Coins.

23. Khaled WAM (2014) Displacement Estimation Analyses for Reconstructive Ultrasound Elastography using Finite-Amplitude Deformations.

24. Art and Virtue Chinese Calligraphy.General Introduction of Chinese Calligraphy.

25. Archaeology News Network (2013) Ancient Chinese Bamboo Texts Tell Medical History.

26. Wikimedia (2010) Kharosthi Script on Wood.

27. Hindman S (1996-2020) A Beginner's Guide to Medieval Manuscripts.

28. RMC Library. Manuscripts on Vellum.

29. Wikimedia Commons (2011) Birch Bark Manuscript of the Utpattiprakarana Moksopaya.

30. Wikimedia Commons (2018) $6^{\text {th }}$-century Brihat Samhita of Varahamihira.

31. Johnson I (2018) How a Chinese Manuscript Written 2,300 Years Ago Ended Up in Washington, The New York Times.

32. Icollector (1996-2020) Chinese Manuscript on Astrology with Drawings, Qing Dynasty.

33. Maxwell K Illuminated Gospel-books.

34. Esther Hecht's Blog (2010) Illuminating the Past: A Look at Rare Jewish Manuscript.

35. Wikipedia (2020) Indian Copper Plate Inscriptions.

36. Friedman M (2012) In a Bronze Inscription, a Remnant of Roman Might.

37. Bidder (2019) Oriental Antique Jewish Manuscript.

38. Canary Promotion (2001-2020) Paper Conservation.

39. Wurl J (2014) Does NEH Still Support Digitization? Why, Of Course!.

40. Mazumdar NR (2015) Status of Manuscript Collection: An Overview, Management of Manuscript Collection in Assam in Digital Era: A Practical Approach Using ICT Tools, Thesis Submitted for the Degree of Philosophy, Department of Library and Information Science, Guwahati University, Guwahati.

41. Mukherjee S (2018) If this Rare Kolkata Museum Shuts Down, Bengal will Lose a Part of its Soul. 